\title{
Remote-Sensing-Based Estimation of Surface Nitrate and Its Variability in the Southern Peninsular Indian Waters
}

\author{
R. K. Sarangi \\ Marine Geo and Planetary Sciences Group, Space Applications Centre (ISRO), Ahmedabad 380 015, India \\ Correspondence should be addressed to R. K. Sarangi, sarangi74@yahoo.com
}

Received 21 May 2011; Accepted 14 October 2011

Academic Editor: Walker Smith

Copyright () 2011 R. K. Sarangi. This is an open access article distributed under the Creative Commons Attribution License, which permits unrestricted use, distribution, and reproduction in any medium, provided the original work is properly cited.

A relationship between sea surface temperature (SST) and surface nitrate concentrations has been obtained for the first time based on in situ datasets retrieved from US JGOFS (1991-96) and Indian cruises (2000-2006) in the Arabian Sea, Bay of Bengal and Indian Ocean region around the southern Indian tip. The dataset includes 1537 points. A sigmoid relationship obtained with $R^{2}$ value 0.912 . NOAA-AVHRR pathfinder satellite monthly averaged SST data retrieved from the PODAAC/JPL/NASA archive during July 1999-June 2004. The datasets imported in the ERDAS-Imagine software and SST images generated on monthly and seasonal scales, for latitudes $5-12^{\circ} \mathrm{N}$ and longitudes $75-85^{\circ} \mathrm{E}$. The ocean surface nitrate images retrieved based on the established sigmoid relationship with SST. The nitrate concentrations ranged between $0.01-3.0 \mu \mathrm{M}$ and categorized into five ranges. The significant seasonal upwelling zone around the southwest coast of India (Kerala coast, Latitude 80.10-9.30 $\mathrm{N}$ and Longitude $\left.75.60-76.20^{\circ} \mathrm{E}\right)$ was identified during July-September $1999-2004$ with very high nitrate concentration $(\sim 1.00 \mu \mathrm{M})$. Low nitrate and nitrate-depleted zones observed during summer (March-May). In the Arabian Sea and northern Indian Ocean, high nitrate concentration $(\sim 0.50 \mu \mathrm{M})$ observed during the southwest monsoon (SWM), whereas the Bay of Bengal was marked with high nitrate $(\sim 0.50 \mu \mathrm{M})$ during the northeast monsoon (NEM). SST was high $\left(\sim 29^{\circ} \mathrm{C}\right)$ in the Bay of Bengal and low $\left(\sim 26^{\circ} \mathrm{C}\right)$ in the Arabian Sea and northern Indian Ocean during SWM and vice versa during the NEM. There is a clear inverse relationship between nitrate and SST in the study area during July 1999-June 2004.

\section{Introduction}

In the upper several hundred meters of the World Ocean, plant nutrient (nitrate, phosphate, and silicic acid) concentrations tend to increase with depth and temperature tends to decrease with depth [1]. This inverse relationship between temperature and plant nutrient concentration also occurs seasonally in surface water to varying degrees depending on geographic location, except at high latitudes where plant nutrients at the surface annually range from a minimal nonzero concentration (as determined by colorimetric methods [2]) to a seasonal maximum concentration related to large-scale geochemical processes $[3,4]$. The spatial and temporal characteristics of the depth distribution of temperature and plant nutrients combine to yield latitudinal-specific relationships in plant nutrients and temperature (PN-T) scatter plots [1]. Incident solar radiation is the primary cause of inverse relationship between water temperature and plant nutrient concentration [5], as a major source of light for phytoplankton photosynthesis and plant nutrient uptake $[6,7]$. Nutrient limitation is much less straightforward than light limitation because of the multiple interactions between nutrients, these interactions being different depending on the scale that is being considered. Until recently, nitrogen was assumed to be the universal limiting nutrient in marine waters. Nitrate is only supplied by diffusion through the thermocline. In the early phase of stratification, chlorophyll concentration is uniform throughout the mixed layer and then a maximum develops at depth near the nitracline.

More specifically, the processes affecting the character of the temperature-nutrient relationship include solar heating, advection and vertical mixing, the rate of nutrient uptake by phytoplankton at the surface, and the rate at which biologically compound organic compounds are regenerated subsurface. Zentara and Kamykowski [8] analyzed temperature-nutrient relationships along the west coast of north America and showed that the slope steepened and the temperature intercept increased at higher latitudes, 
presumably due to latitudinal variation in solar heating. They also noted that variability was greatest in boundary regions where a mixture of water masses is expected. H. J. Minas and M. Minas [9] suggested that the PN$\mathrm{T}$ plots can be used to indicate the intensity of nutrient uptake, by phytoplankton in upwelling areas, with steeper slopes indicating faster nitrate uptake. Under conditions of low phytoplankton uptake the PN-T relationship can be used to study physical processes. The simple model leads to the key concept of new and regenerated production as based on nitrate and ammonia [10]. There has been clear evidence of nitrate utilization with a deepening of nutrient depletion with time. The vertical distribution of chlorophyll concentration also changed with time. Nitrate was the dominant nitrogen source for phytoplankton. The uptake rates measured decreased with declination of nitrate concentration. The current study is based to observe/monitor the distribution of nitrate-nitrogen in the ocean surface. More research is needed to understand the source of nitrate and its flux and know the distribution pattern in regional, and seasonal and intraseasonal timescales. The nitrate-temperature relationships from the drogue depth occasionally suggested and enhanced the heating per unit of nitrate uptake compared to the date from the hydrographic sections. The most direct approach towards a more robust description of the relationship between temperature and plant nutrients in the upper ocean may result from biological additions and relatively subtle physical adjustments to more complete, existing models [11] of the upper ocean mixed layer.

Nitrate transport into the euphotic zone in the southwest, northeast, and intermonsoon phases has been estimated using the satellite-derived SST images, and this agrees with the measured nitrate uptake rates and phytoplankton productivity. It is therefore suggested that the satellitederived nitrate images can be useful tool for assessing nitratebased productivity over large geographical areas in short time intervals. Surface temperature, nutrients, and primary productivity relate to each other [1], and prediction of new production from transformation of satellite-derived temperature images to nitrate distribution is a distinct possibility $[12,13]$. The regularity of the phenomenon unlike temporally variable upwelling and the fact that the phytoplankton growth was stimulated after each spring tide lead one to use SST measurements from satellite infrared radiance to predict nitrate input to the euphotic zone and thereby compute resultant production [14].

A major fraction of the carbon transported into the oceans interior is associated with allochthonous nitrogen inputs, primary nitrate $(\mathrm{N})$, into the euphotic zone $[15,16]$. Hence, understanding the spatial and temporal variations of $\mathrm{N}$ over basin and global scales in the euphotic layer is an important requirement for ocean biogeochemical and climate studies [16]. Although $\mathrm{N}$ in seawater lacks a distinct electromagnetic signature that can be utilized for its estimation from space, satellites have for long been suggested as a promising measurement tool, because $\mathrm{N}$ correlates well with certain remotely measurable seawater properties [17]. The relationship between $\mathrm{N}$ and seawater temperature $(\mathrm{T})$, for instance, has consistently been found to be negative as nutrient-rich waters brought up into the euphotic zone from the deep by physical processes such as upwelling or winter convective overturning are colder than the surface waters which are generally nutrient poor. Although empirical algorithms based on PN-T relationships have been existent for a while $[14,18-20]$, Goes et al. [21] have shown that if biologically modified changes in the character of PN-T relationships are taken into account, it is possible to generate high-resolution maps of surface nitrate over much larger spatial and temporal scales than previously possible.

The Labrador Sea Monitoring Program (LSMP) annual spring-summer missions measure seasonal nutrient concentrations but not winter maximums nor summer minimums for the most part, which are critical for $\mathrm{P}_{\text {new }}$ estimation [22]. The wintertime nutrients in the North Atlantic are new approaches and implications for new production estimates [22]. Another recent approach, worldwide applicable, is that proposed by Kamykowski et al. [23] and Switzer et al. [24]. They generated a scaled index of nitrate availability by computing the differences between SST (derived from AVHRR data) and "nitrate depletion temperatures" (NDT), inferred from in situ data and geographically variable. Satellites have been suggested as a useful alternative. Although they can provide frequent, large-scale, near-surface views of several variables relevant to phytoplankton ecology such as incident radiation, chlorophyll, and sea surface temperature (SST), nutrient measurements have remained elusive as most nutrients including nitrate lack an electromagnetic signal that can be exploited from space [25]. Henson et al. [26] derived their empirical relationships between surface nitrate (or silicate) and temperature and chlorophyll using broad spatial distributions of these variables at $5 \mathrm{~m}$ depth collected on four missions between November 2001 and December 2002 in the Irminger Basin.

Silió-Calzada, et al. [27] has proposed a new approach to estimate $\mathrm{NO}_{3}$ specifically developed for areas influenced by upwelling processes. It relates the nitrate concentration to the difference between SST and the estimated temperature of the upwelled water (variable with latitude and season), which is an indicator of the time elapsed since upwelling. Algorithm has been developed using multiple linear regression (MLR) from nitrate, SST, and mixed layer depth (MLD) data in the North Atlantic Ocean [28]. The N-T relationships, however, are strongly influenced by the regional biogeochemical characteristics and hydrodynamic conditions and therefore reveal a high spatial and temporal variability. The current study is the first attempt to show those relationships in Indian waters with the collection of 1537 data points retrieved from U.S. JGOFS (1991-1996) and Indian cruises (19972002) database. The purpose of this work is to formulate a preliminary integrated model of water temperature and nitrate concentration, to examine the influence of the various terms in the model, and to identify future directions for improved models.

Rationale for this study is to find out the role of nitrate in the ocean biogeochemical cycling, mostly its role in new primary production. The new production is 
bestowed upon the carbon cycle in specific areas in sea like upwelling, eddies, convection, detrainment, and even in algal bloom conditions. The nitrate has a significant role on the growth, metabolism, and in euphotic-zonebased photosynthesis/productivity of the phytoplankton so it is recognized as a major limiting factor, even most of the blooms occur due to the enrichment of nitrate, the cyanobacteria Trichodesmium sp. fixes the atmospheric nitrogen and blooms. The normal inverse trend of ocean surface nitrate is related to the temperature of water. The bottom nitrate or the nitrate from water column being carried up with column water and hence the higher nitrate and low temperature has been observed in the surface. Here in the current study the relationship has been accurately represented finding its sigmoid curve. The results over Indian southern peninsular water have been exclusively discussed for five-year data and generated nitrate images.

This study is important from the point of view of climate change, such that shipboard datasets from several years have to be combined with generate maps of nitrate at global scale and this would enhance the daily, monthly, seasonal, and interannual scale variations of marine nitrate. In previous and on-going studies, the immense promise and potential of satellite-based nitrate maps for carbon cycling and climate change studies have been demonstrated [29]. Climate forcing greatly impacts processes controlling the distribution of nutrients and hence the productivity. The nutrient distribution also gives the indication about the physical processes interaction in the region of study.

\section{Study Area}

The present study has been carried out in the southern peninsular Indian waters, which include a part of the Arabian Sea, Bay of Bengal, and Indian Ocean. This is an interesting area, because it consists of three different water types with their own productivity potential and other environmental features (Figure 1).

The physicochemical and biological properties of the Arabian Sea, are affected by monsoon reversal wind systems. The monsoon wind affects the chlorophyll distribution pattern besides other properties [30]. Several phenomena like the high concentration of algae occur during winter as a consequence of vertical convection. Several other interesting phenomena like upwelling and its season-specific increase in algal biomass are also noticed as common events in this sea [31]. The southern tip of India is associated with Indian Ocean. Mixing and convergence takes place between the waters of the Arabian Sea and the Bay of Bengal [32]. The shelf flow also determines the productivity pattern of the Indian Ocean. The Bay of Bengal is activated by the cyclonic winds, storms, gyres and sea surface is rough compared to the Arabian Sea [33-38].

Unlike the northern Bay of Bengal, the southern part happens to be generally nutrient limited largely due to limitations in external river inputs. The southern rivers are often seasonal and bring external nutrients only during shorter monsoon/postmonsoon periods. The Bay of Bengal,

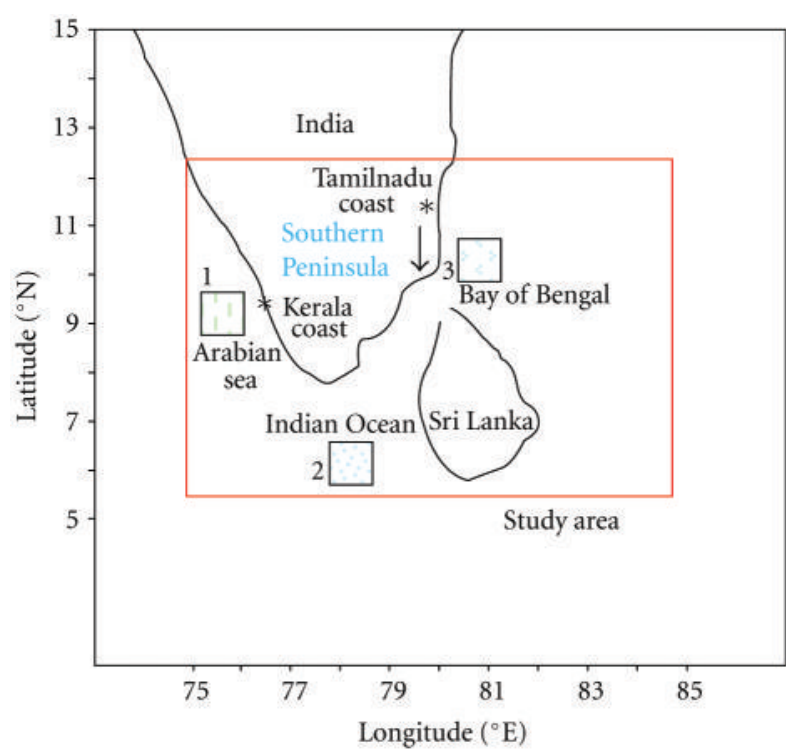

Figure 1: Study area (latitude: $5.5^{\circ}-12^{\circ} \mathrm{N}$ and longitude: $75^{\circ}-84^{\circ} \mathrm{E}$ ) indicating the Arabian Sea, Indian Ocean, and the Bay of Bengal with the boxes drawn for analysis $(1,2,3)$.

in general, is a data-poor region compared to the rest of the Indian Ocean. Despite its importance, shipboard nitrate measurements fall far short of the space and time scales required for climate research. The nitrate has important role to demonstrate the high productivity and new production zones in different seasons in Indian water. There are limited numbers of studies for Bay of Bengal waters with reference to ocean remote sensing. A detailed study is required to understand the surface nitrate dynamics on time-series basis.

\section{Materials and Methodology}

3.1. Generation of SST Composite Images. The NOAAAVHRR Pathfinder-5 based monthly averaged SST ASCII data with latitude, longitude, and SST columns were retrieved from the http://www.nasa.gov/ archive for the period July 1999-June 2004. The datasets were imported in the ERDAS Imagine software to generate the SST images in monthly scales during the period July 1999-June 2004. The monthly images were averaged to seasonal composite images covering the latitude $5^{\circ}-12^{\circ} \mathrm{N}$ and longitude $75^{\circ}-85^{\circ} \mathrm{E}$. The images were gridded and colour coded using ERDAS Imagine and Envi software. The clouds and unavailable data have been displayed blank in the images. The Pathfinder- 5 sensor ascending/morning pass data of resolution 4 kilometers has been used and provides SST with accuracy of $0.3^{\circ} \mathrm{C}[39,40]$.

3.2. Nitrate Retrieval Algorithm. In this study an attempt was made to find the relationship between nitrate and temperature from the U.S. JGOFS dataset for the Arabian Sea (1994-1997) and Indian cruise datasets (2000-2006) covering the Arabian Sea and Bay of Bengal. A linear relationship has been established in the European waters [14]. 


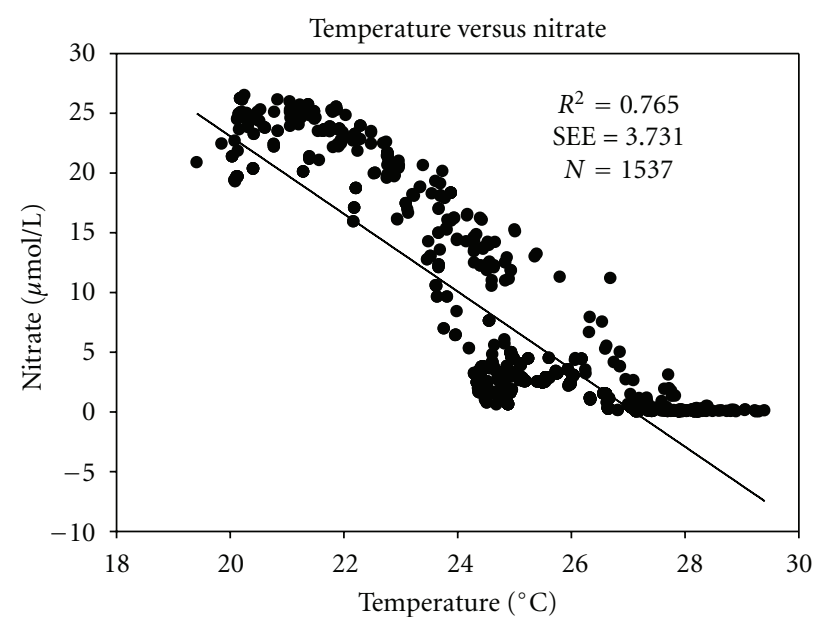

(a)

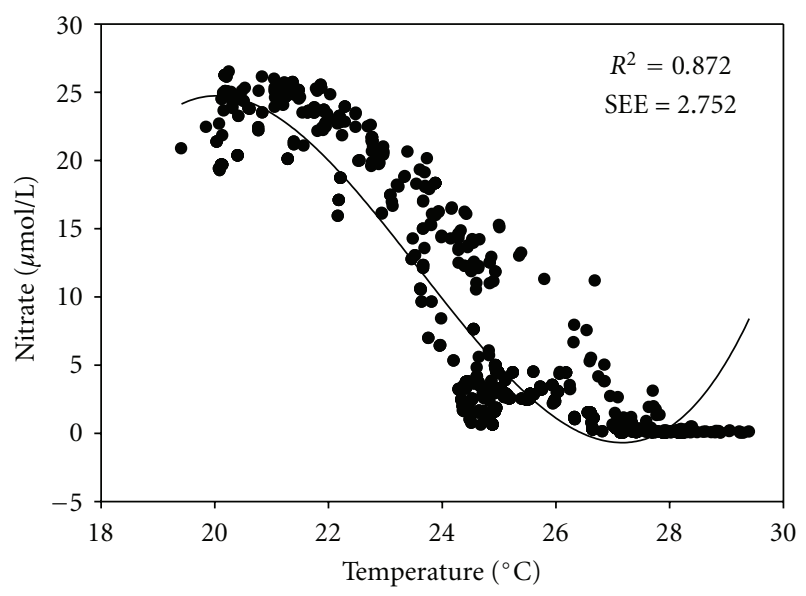

(c)

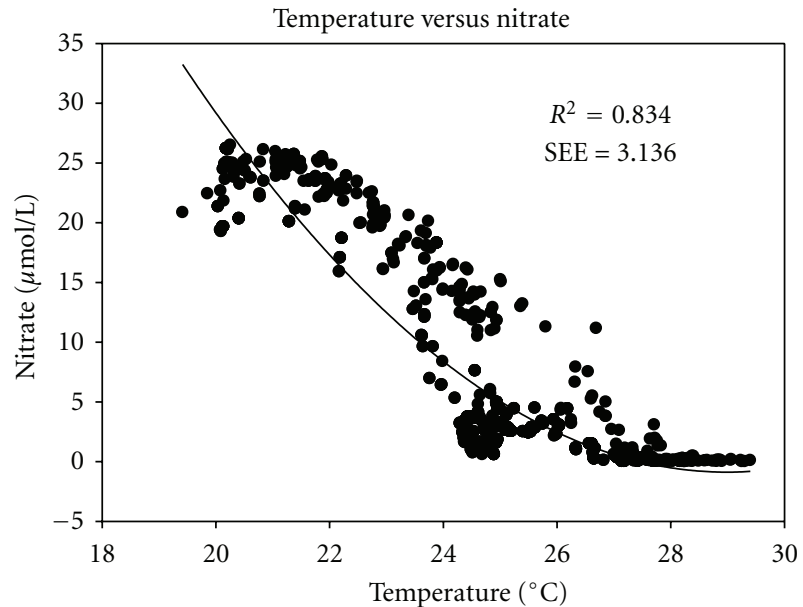

(b)

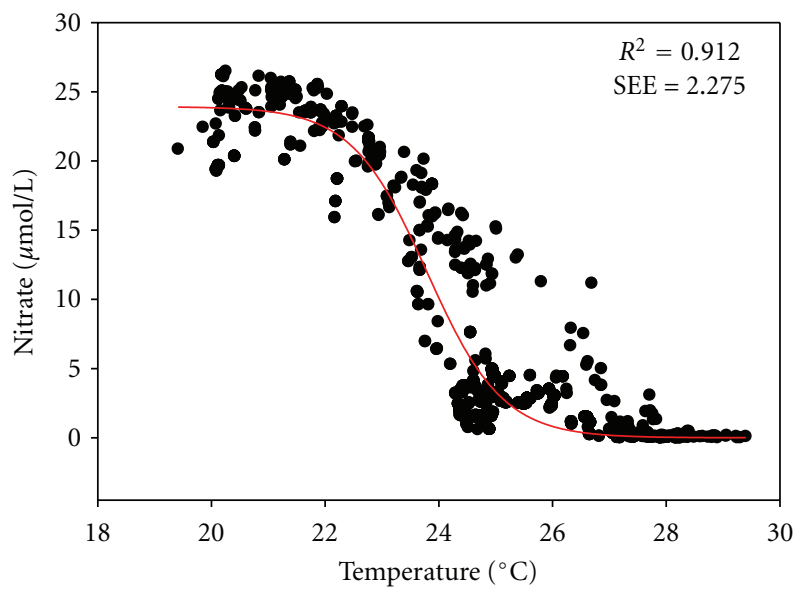

(d)

Figure 2: Linear, polynomial (2nd and 3rd order), and sigmoid ((a), (b), (c), and (d)) relationships between temperature and nitrate have been displayed for the Arabian Sea data collected from JGOFS and Indian cruises.

The ocean surface nitrate concentration has been retrieved based on the established relationship as follows.

The regression best fit gives the following equation:

$$
\text { Nitrate }\left(\mathrm{NO}_{3}\right)=\frac{23.924}{\left[1+\mathrm{e}^{\{(\mathrm{SST}-23.793) / 0.662\}}\right]} .
$$

$R^{2}=0.912$. Standard Error of Estimate $=2.2755$.

Linear, polynomial (2nd and 3rd order), and sigmoid relationship between in situ retrieved temperature and nitrate data has been established for the Arabian Sea data collected from JGOFS and Indian cruises. The respective $R^{2}$ values have been observed to be $0.765,0.834,0.872$, and 0.912 . The respective standard error of estimate (SEE) has been observed 3.731, 3.136, 2.752, and 2.275 for the 1537 data points. So, the sigmoid relationship has been found with the best curve fitting (Figures 2(a)-2(d)). Figure 3 displays a regression plot indicating the relationship of in situ nitrate data from Indian cruises with pathfinder and MODIS-Aquaderived SST. The nitrate-algorithm-derived nitrate image and data points have been validated with the 13 in situ data retrieved during 2003 February and March cruises in the Arabian Sea on board cruises of ORV "Sagar Kanya" and FORV "Sagar Sampada." Validation result with the available 13 in situ points from Indian cruises has shown the $R^{2}$ value 0.843 (Figure 3(a)). Validation result of in situ nitrate with SST from the available cloud-free satellite passes of Pathfinder (February-March 2003) has shown the $R^{2}$ value 0.815 (Figure 3(b)). Even, the relationship of nitrate with other corollary parameters like chlorophyll and wind speed has been taken attempt besides SST (Figures 4(a), 4(b), 4(c)).

3.3. Generation of Nitrate Images. The monthly, seasonally averaged nitrate composite images have been generated for the study area. The monthly images were averaged to seasonal composite images with the category of seasons; (1) southwest monsoon (SWM)-June-September, (2) fall intermonsoon (FIM)-October-November, (3) northeast monsoon (NEM)-December-March, and the (4) spring intermonsoon (SIM)_April-May [41] (Figures 5, 6, 7, 8, 9, 10 and 11). 


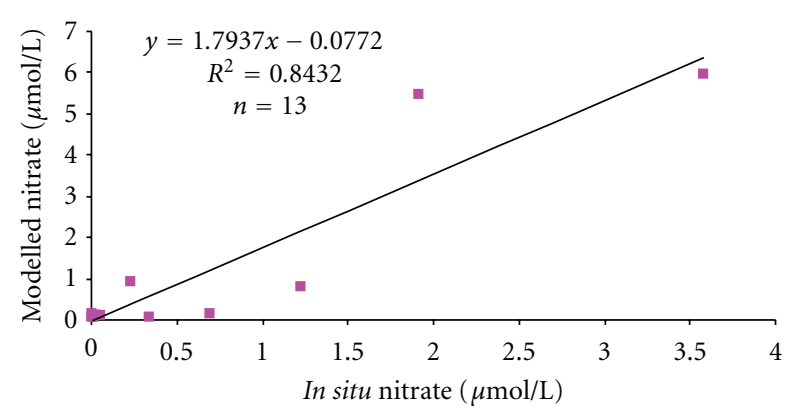

(a)

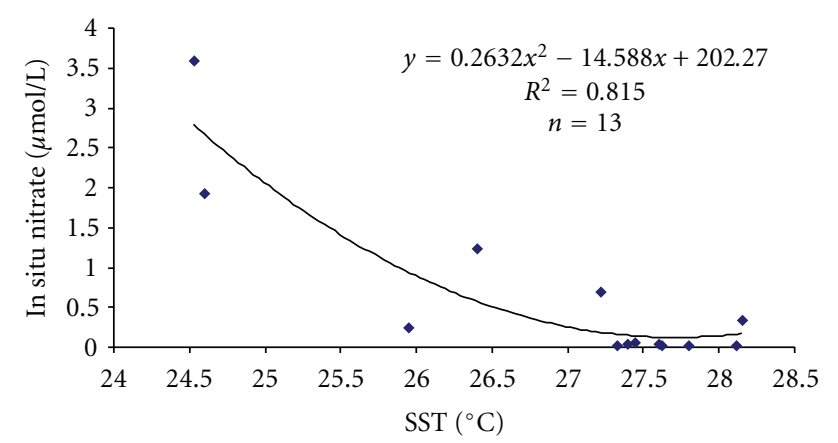

(b)

Figure 3: ((a), (b)) Regression plots displaying the relationship of in situ nitrate from Indian cruises with modeled nitrate data and with pathfinder (February-March 2003) derived SST data.

3.4. Subset and Transect Data Retrieval. We focus on the three different seas to reflect their properties in terms of satellite-derived SST and nitrate concentrations and their interrelationship. This region is very significant from the point of view of its oceanography, regulated by all the four monsoons, related coastal/oceanic features, circulations, and currents.

The pockets/boxes were taken from the three different oceans: (1) Arabian Sea (latitude: $8.95-9.95^{\circ} \mathrm{N}$ and longitude: $74.6^{\circ}-75.6^{\circ} \mathrm{E}$ ), (2) Indian Ocean (latitude: $6.24^{\circ}-$ $7.24^{\circ} \mathrm{N}$ and longitude: $77.1^{\circ}-78.1^{\circ} \mathrm{E}$ ), and (3) Bay of Bengal (latitude: $10.2^{\circ}-11.2^{\circ} \mathrm{N}$ and longitude: $80.4^{\circ}-81.4^{\circ} \mathrm{E}$ ) (Figure 1). The three pockets are off the coast and covering the water in the depth ranges to 1000-3000 meter (http://www.ngdc.noaa.gov/mgg/bathymetry/relief.html).

The pixels/data points falling in the pockets $(1,2,3)$ were respectively averaged to generate subset images for the parameters SST and nitrate. The mean and standard deviation of the respective months and seasonal composites have been calculated and plotted. Monthly mean and standard deviation data for each pocket has been plotted as line plots, and the seasonal, annual, and four-year composite has been plotted as histogram/bar charts to understand the variability in respective time scale and seasons. The colour-coded images for each parameter SST and nitrate concentration have been displayed for different time scales with respective colour scale ranges, namely, SST $\left(22^{\circ}-30^{\circ} \mathrm{C}\right)$ and nitrate $(0.01-3 \mu \mathrm{M})$ (Figures 10,11$)$.

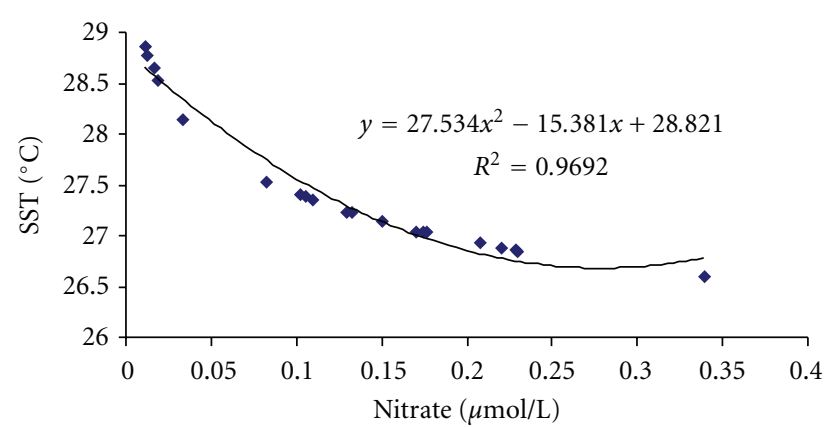

(a)

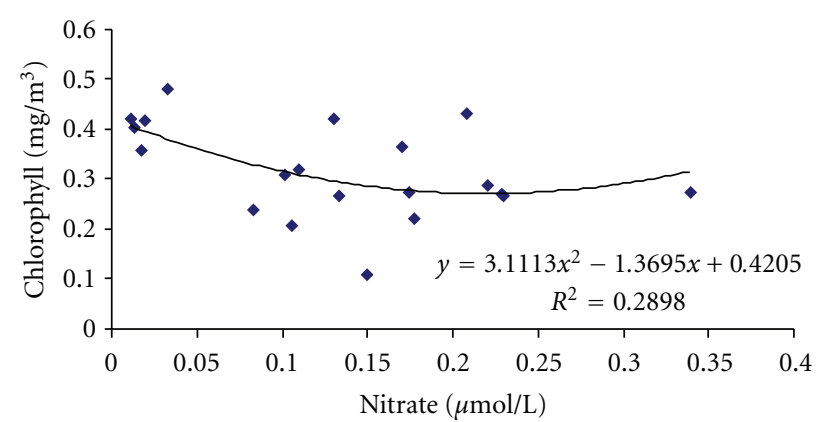

(b)

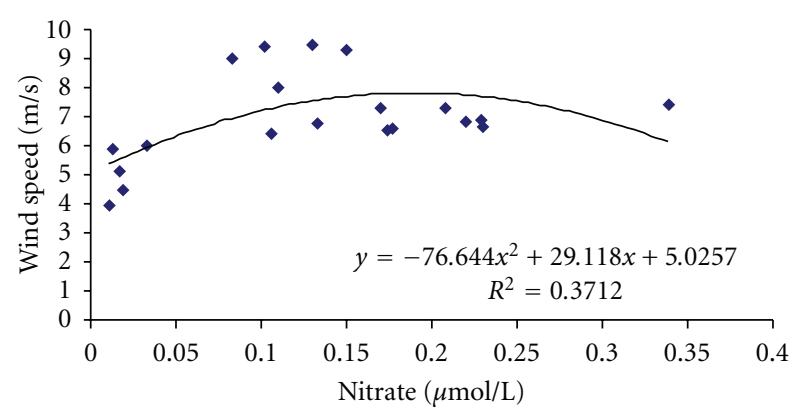

(c)

FIGURE 4: Regressions plots are displayed indicating the relationship of nitrate with SST, chlorophyll, and wind speed, retrieved from modeled and satellite datasets for April 2000 covering southern peninsular Indian water.

\section{Results and Discussion}

4.1. Variability of Nitrate $\left(\mathrm{NO}_{3}\right)$. The nitrate concentration varied depending on the conditions like the four monsoon seasons and respective months and on the regional scale. The nitrate distribution has been classified into five categories depending on the nitrate ranges $\left(<0.2=\right.$ low $\mathrm{NO}_{3}$ zone, $<0.50$ $=$ medium zone, $<1.0=$ high $\mathrm{NO}_{3}$ zone, $<3.0=$ very high $\mathrm{NO}_{3}$ zone, $0=$ land mass and $\mathrm{NO}_{3}$-depleted zone).

4.2. Monthly Scale Nitrate Images. During this period the medium, high, and very high nitrate zones have been observed around the Gulf of Mannar and in the southern tip of Indian region. The stretches of high nitrate have been observed along the Kerala coast in the Arabian Sea, which indicates and supports the foresaid and earlier studied upwelling events with our nitrate maps (Figure 5). 

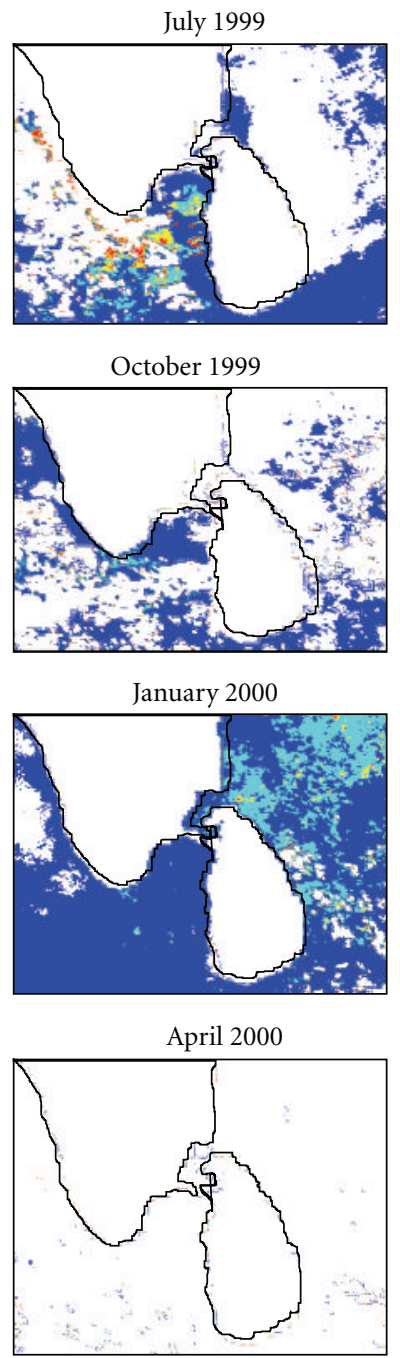

Nitrate ranges $(\mu \mathrm{mol} / \mathrm{L})$

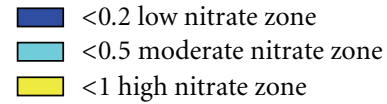

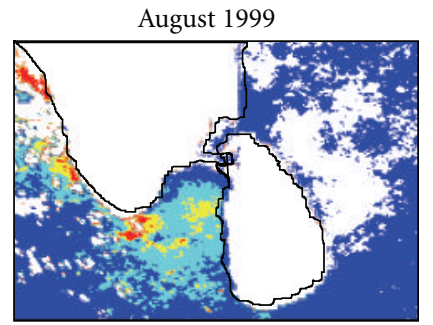
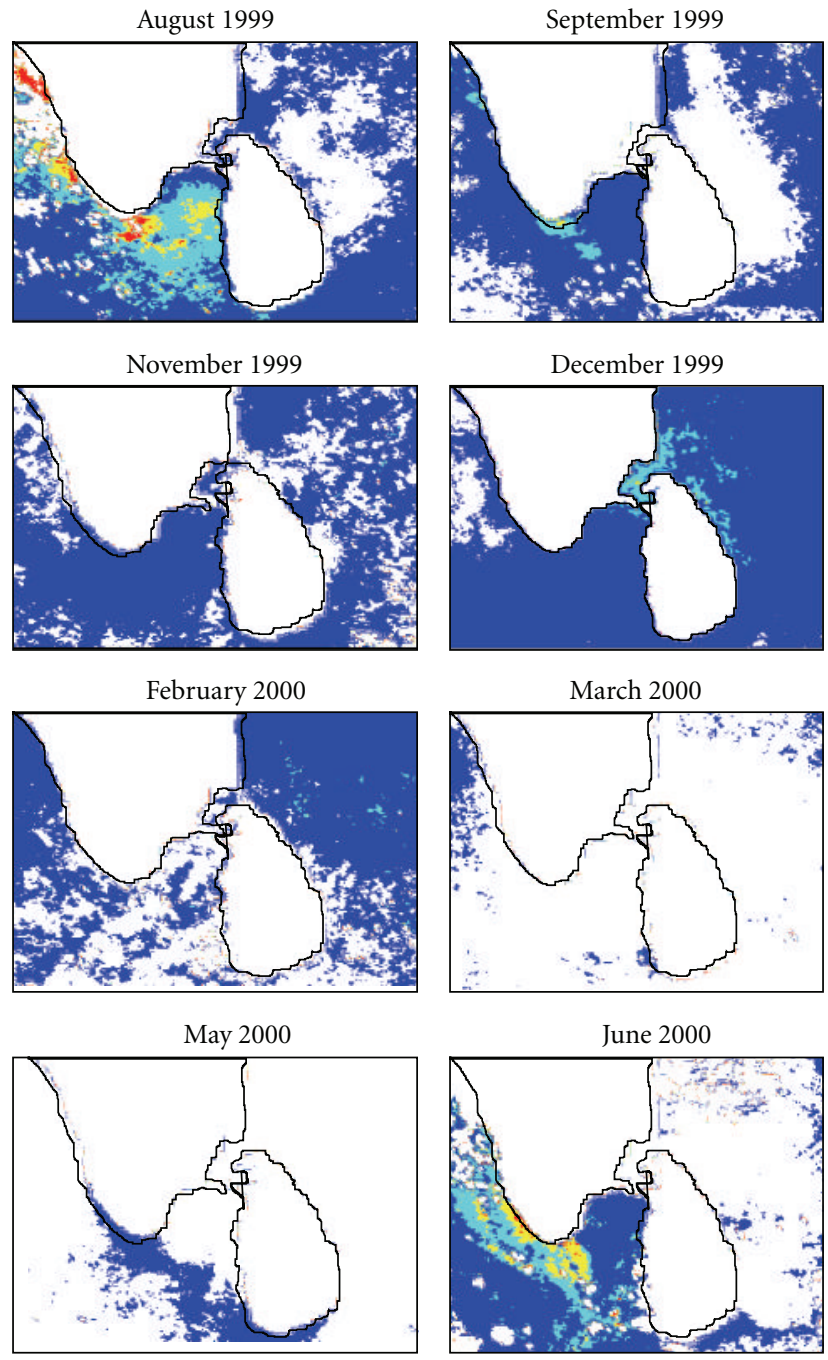

$<3$ very high nitrate zone

0 land and nitrate-depleted zone

FIGURE 5: In situ nitrate- and temperature-based modeled monthly composite nitrate images during July 1999-June 2000 retrieved from NOAA-AVHRR pathfinder data.

The upwelling has been reflected in the nitrate maps of July and August 1999. Even during the June month, the event has been seen along the Kerala coast (latitude $80.10-9.30^{\circ} \mathrm{N}$ and longitude $75.60-76.20^{\circ} \mathrm{E}$ ). During September and October, the moderate nitrate patches have been observed at the bottom of Indian southern peninsula. Large nitrate-depleted areas can be observed in the Arabian Sea and in the Bay of Bengal during the months July-October.

In December, around the Gulf of Mannar and in the east coast of Sri Lanka, moderate $\mathrm{NO}_{3}$ range patches have been observed and, during January, it has become intense in the Bay of Bengal. During February, low nitrate patches are seen in the Bay of Bengal and Arabian Sea, and nitratedepleted zones have been observed in the northern Indian Ocean. March-May indicated the nitrate-depleted zones throughout, and, in the month of May, low $\mathrm{NO}_{3}$ stripe has been seen from the bottom of India moving towards the Sri Lankan bottom. During June, the Arabian Sea indicated low nitrate zone with moderate, high, and very high $\mathrm{NO}_{3}$ stripes along Kerala coast and offshore. The Bay of Bengal indicated $\mathrm{NO}_{3}$-depleted water during June (Figure 5).

During July 2000, the Kerala coast/southeast coast of India has reflected high upwelling zone with high $\mathrm{NO}_{3}$ concentration (Figure 6). rest of the study area showed low $\mathrm{NO}_{3}$ concentration zones, and similar patterns are seen. The upwelling has been observed during the period June-August (SWM) around Kerala coast and off southeast Arabian Sea with medium, high, and very high $\mathrm{NO}_{3}$ concentration bands. High $\mathrm{NO}_{3}$ concentration patches have been seen during January (NEM) in the Bay of Bengal water with moderate, high, and very high $\mathrm{NO}_{3}$ concentration zones (Figures 5-9), (Table 1). 


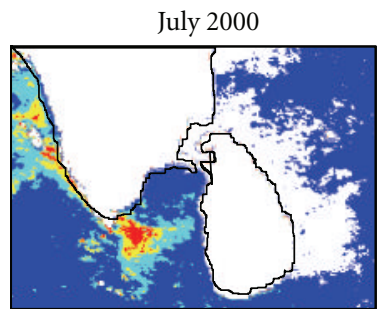

October 2000

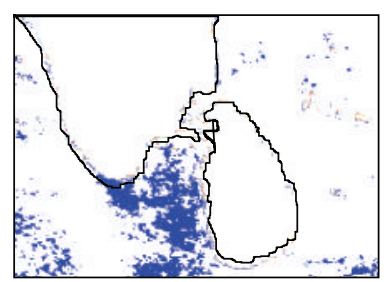

January 2001

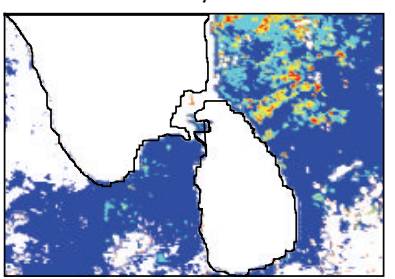

April 2001

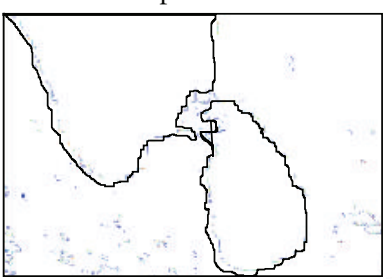

Nitrate ranges $(\mu \mathrm{mol} / \mathrm{L})$

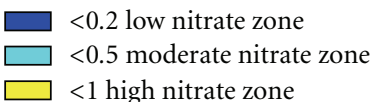

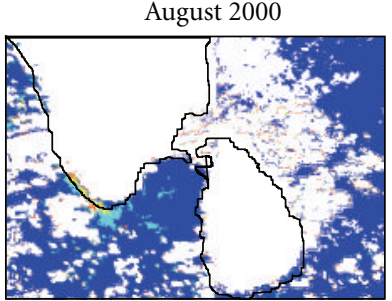

November 2000

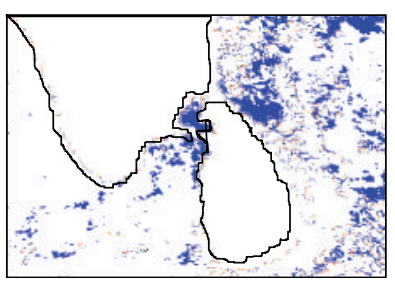

February 2001

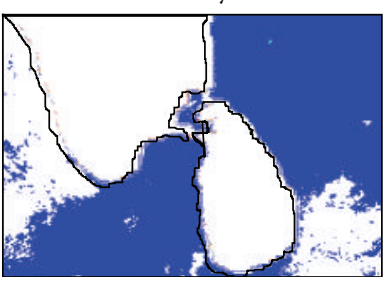

May 2001

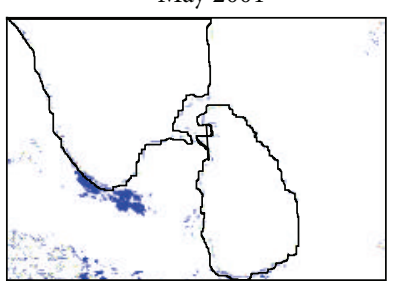

September 2000

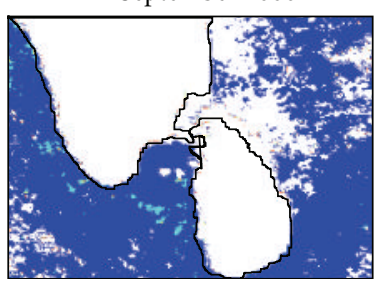

December 2000

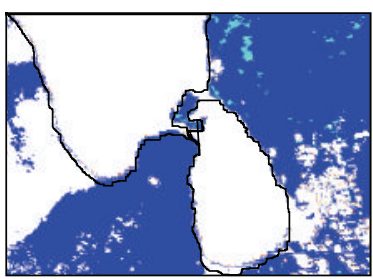

March 2001

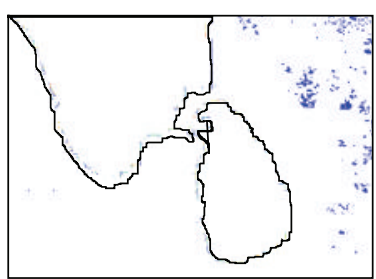

June 2001

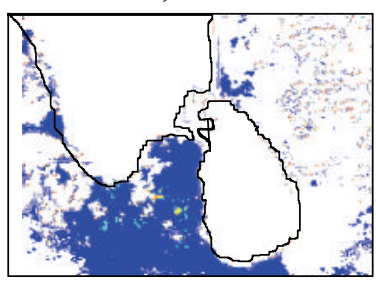

$\square<3$ very high nitrate zone

$\square$ 0land and nitrate-depleted zone

Figure 6: In situ nitrate- and temperature-based modeled monthly composite nitrate images during July 2000-June 2001 retrieved from NOAA-AVHRR pathfinder data.

TABle 1: Depiction of high nitrate distribution months in the Indian water.

\begin{tabular}{ll}
\hline Study Area & High nitrate/months \\
\hline Arabian Sea & June-September \\
Indian Ocean & June-September and December-February \\
Bay of Bengal & December-February \\
${ }^{*}$ April-May showed fully $\mathrm{NO}_{3}$-depleted zones throughout the study area.
\end{tabular}

4.3. Interpretation of Seasonal SST Images. Figure 10 indicates the seasonal variability of SST in the southern peninsular Indian water. There has been observation of high SST $\left(\sim 29^{\circ} \mathrm{C}\right)$ in the Bay of Bengal during the southwest monsoon and low SST $\left(\sim 25^{\circ} \mathrm{C}\right)$ in the Arabian Sea and around southern Indian tip region. The SST was exceptionally low $\left(\sim 24^{\circ} \mathrm{C}\right)$ during the fall intermonsoon 2001 around the southern tip of India in the Indian Ocean. During northeast monsoon, SST was low in the Bay of Bengal $\left(\sim 25^{\circ} \mathrm{C}\right)$ and high in the Arabian Sea $\left(\sim 29^{\circ} \mathrm{C}\right)$ and medium $\left(\sim 27^{\circ} \mathrm{C}\right)$ in the southern Indian tip in the Indian Ocean. During spring intermonsoon, low SST $\left(\sim 25^{\circ} \mathrm{C}\right)$ patches were seen around the southern Indian tip in the Indian Ocean.

4.4. Interpretation of Seasonal Nitrate Images. The seasonal $\mathrm{NO}_{3}$ maps indicated the high and very high $\mathrm{NO}_{3}$ concentration stripe along Kerala coast/southeast coast of India during the SWM season. Few high concentration patches were seen during the NEM, and rest of the months show low $\mathrm{NO}_{3}$ in the Bay of Bengal and $\mathrm{NO}_{3}$-depleted zone in the Arabian Sea (Figure 11). During the season spring intermonsoon (SIM), completely $\mathrm{NO}_{3}$-depleted zones have been seen in the study area. Fall inter monsoon (FIM) showed mostly $\mathrm{NO}_{3}$ depleted zones throughout with few low $\mathrm{NO}_{3}$ patches in the north Indian Ocean during 2000-2003. But, during the year 1999, 

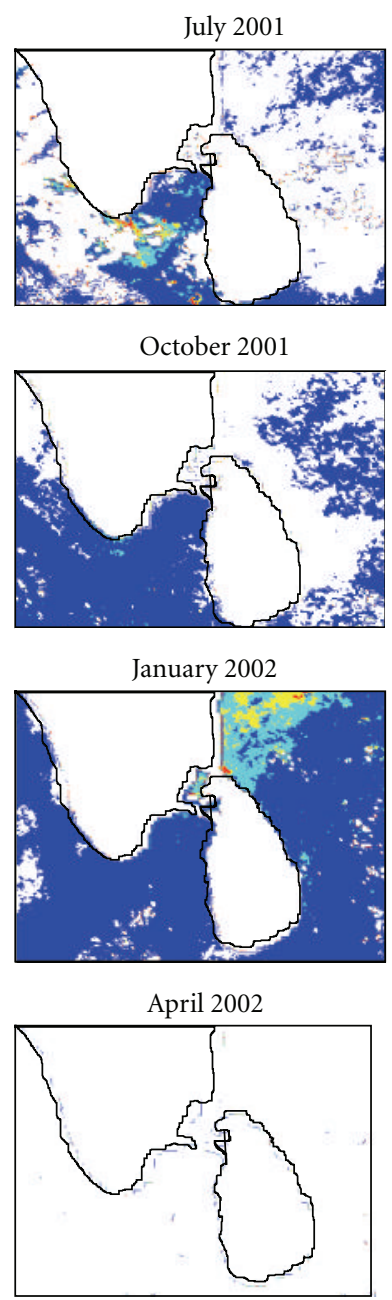

Nitrate ranges $(\mu \mathrm{mol} / \mathrm{L})$

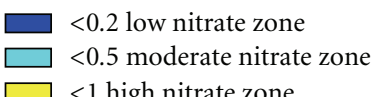

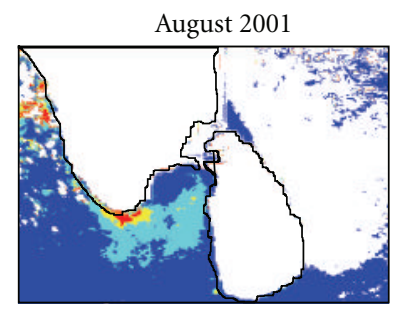

November 2001

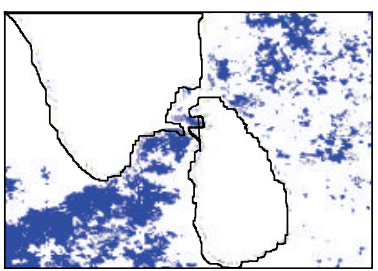

February 2002

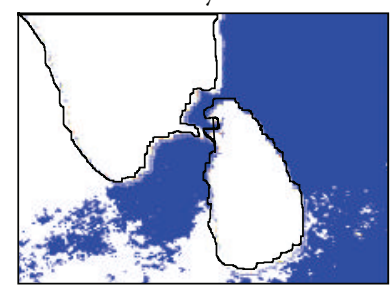

May 2002
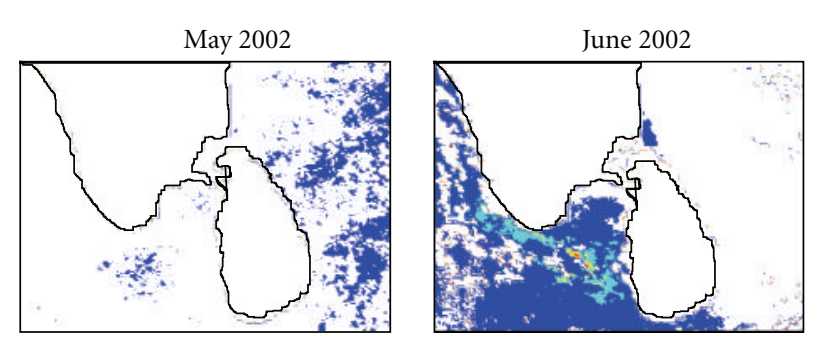

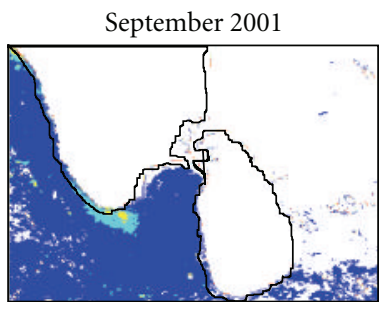

December 2001
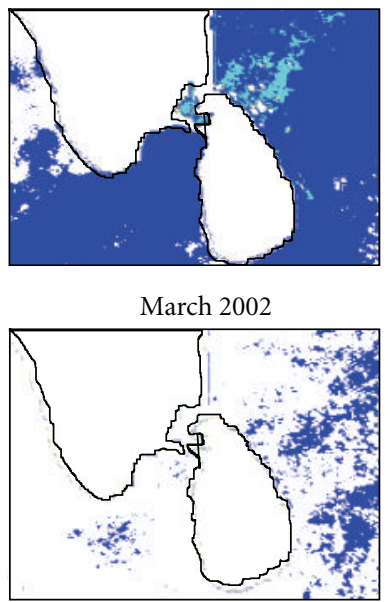

$<3$ very high nitrate zone

0 land and nitrate-depleted zone

FIGURE 7: In situ nitrate and temperature based modeled monthly composite nitrate images during July 2001-June 2002 retrieved from NOAA-AVHRR pathfinder data.

the FIM (October-November) indicated the distribution of low $\mathrm{NO}_{3}$ throughout the study area, probably enhanced with the super cyclone that had hit the northeast coast of India/Orissa during October 1999 with very high wind speed $(>200 \mathrm{~m} / \mathrm{sec})$ and storm surges with wave heights $(\sim 20$ meter) [42]. The super cyclone might have mixed the surface and bottom water, making the water turbulent, churning nutrients, and bringing up to surface. So, the exceptional widespread of $\mathrm{NO}_{3}$ has been observed during FIM 1999. The sources of nitrate can be from terrestrial origin as observed during the NEM and FIM in the Indian Ocean and the Bay of Bengal. The sources can be from the bottom and deep water of ocean as the case of upwelling in the southwest coast of India during SWM (Figure 11).

4.5. Monthly Scale Nitrate Variability/Line Plots. The monthly mean nitrate peaks have been observed to be highest with two major peaks during the months August 1999 and January $2000(\sim 0.13 \mu \mathrm{M})$, and the monthly mean is lowest with two low dips during October and March $\left(\mathrm{NO}_{3} \sim 0.01 \mu \mathrm{M}\right)$ (Figure 12).

4.5.1. Subset 1. For the subset 1 the monthly mean nitrate concentration has been seen highest during June-August (SWM) months $(0.09-0.71 \mu \mathrm{M})$ and similar in all the years. The rest of the months indicated less variability and equal trend during all the five-year period (Figure 12).

4.5.2. Subset 2. For the subset 2 of the study area, the northern Indian Ocean, the mean $\mathrm{NO}_{3}$ peak has been obtained during the SWM and FIM seasons. The peak is seen in the month of October $(0.6 \mu \mathrm{M})$ and during May-August, with the effect of onset and activation of SWM in the northern 

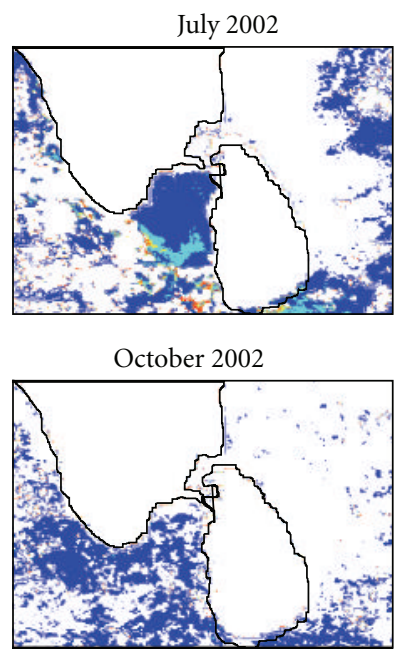

January 2003

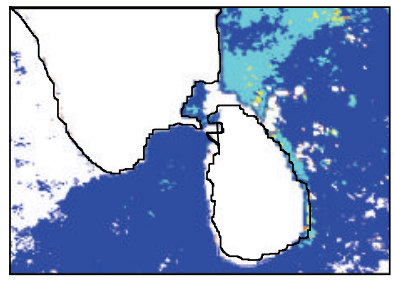

April 2003

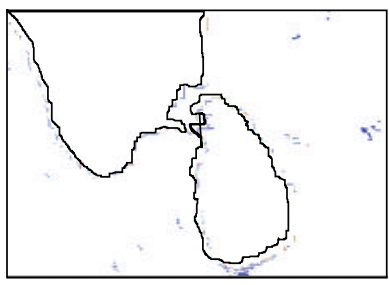

Nitrate ranges $(\mu \mathrm{mol} / \mathrm{L})$

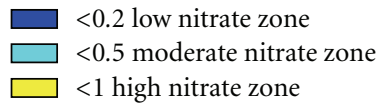

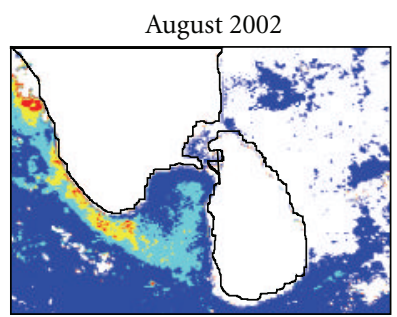

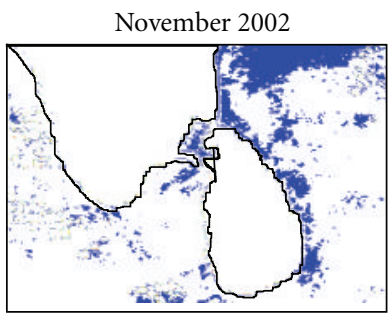

February 2003

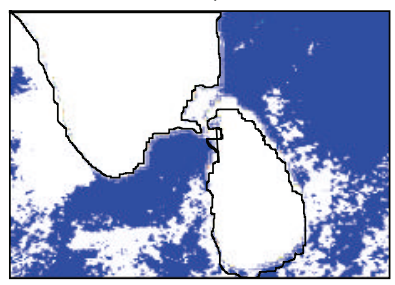

May 2003

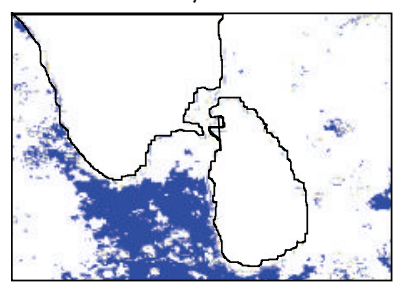

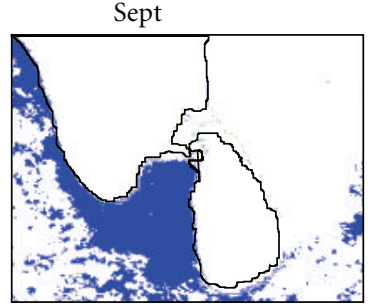

December 2002

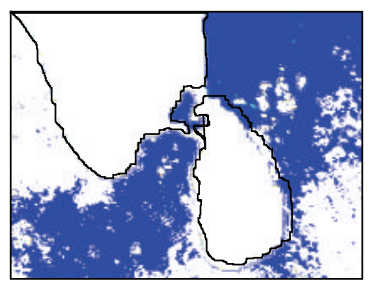

March 2003

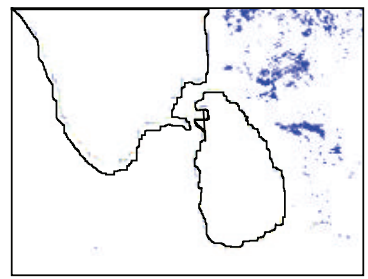

June 2003

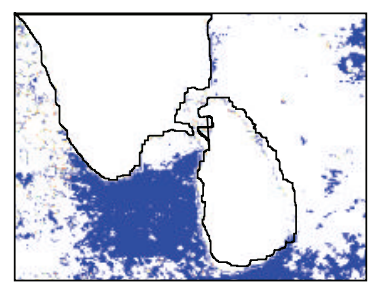

$<3$ very high nitrate zone

0 land and nitrate-depleted zone

FIGURE 8: In situ nitrate- and temperature-based modelled monthly composite nitrate images during July 2002-June 2003 retrieved from NOAA-AVHRR pathfinder data.

Indian Ocean region. January month (NEM) shows a small peak in the $\mathrm{NO}_{3}$ concentration $(0.09 \mu \mathrm{M})$ (Figure 12). The rest of the months do not indicate any peak and more variability. So, the Indian Ocean is mostly affected by high $\mathrm{NO}_{3}$ during SWM and NEM months.

4.5.3. Subset 3. The case is different for the Bay of Bengal. The $\mathrm{NO}_{3}$ concentration has been highest during the month of January (Figure 12). The peak of nitrate has been evidenced by other months between November and February for all the years. There is no impact of SWM and enhancement of $\mathrm{NO}_{3}$ in the Bay of Bengal, like it was in the case of Arabian Sea and to some extent in the Indian Ocean.

\subsection{Variability of Surface Nitrate $\left(\mathrm{NO}_{3}\right) /$ Histogram Plot}

4.6.1. Full Image. The seasonal nitrate $\left(\mathrm{NO}_{3}\right)$ trend has been observed significantly. The $\mathrm{NO}_{3}$ range was highest during
SWM $(0.05-0.098 \mu \mathrm{M})$ and with the year-wise trend: $1999>$ $2000>2001>2002>2003$.

The trend was lowest during SIM $(0.008-0.021 \mu \mathrm{M})$ (Figure 13). The seasonal nitrate trend is as follows: SWM > NEM $>$ FIM > SIM.

4.6.2. Subset 1 (Arabian Sea). The seasonal nitrate $\left(\mathrm{NO}_{3}\right)$ trend has been observed significantly for the Arabian Sea surface water. The nitrate mean range was highest during SWM $(0.06-0.198 \mathrm{uM})$ with the year-wise trend $2000>1999$ $>2001>2002>2003$. The nitrate mean range is lowest during NEM (0.005-0.015 uM) (Figure 13). The seasonal trend is as follows: SWM $>$ FIM $>$ SIM $>$ NEM.

4.6.3. Subset 2 (Indian Ocean). The seasonal mean $\mathrm{NO}_{3}$ range has been highest during the SWM $(0.07-0.205 \mathrm{uM})$ with the year-wise trend $1999>2000>2001>2002>2003$. 

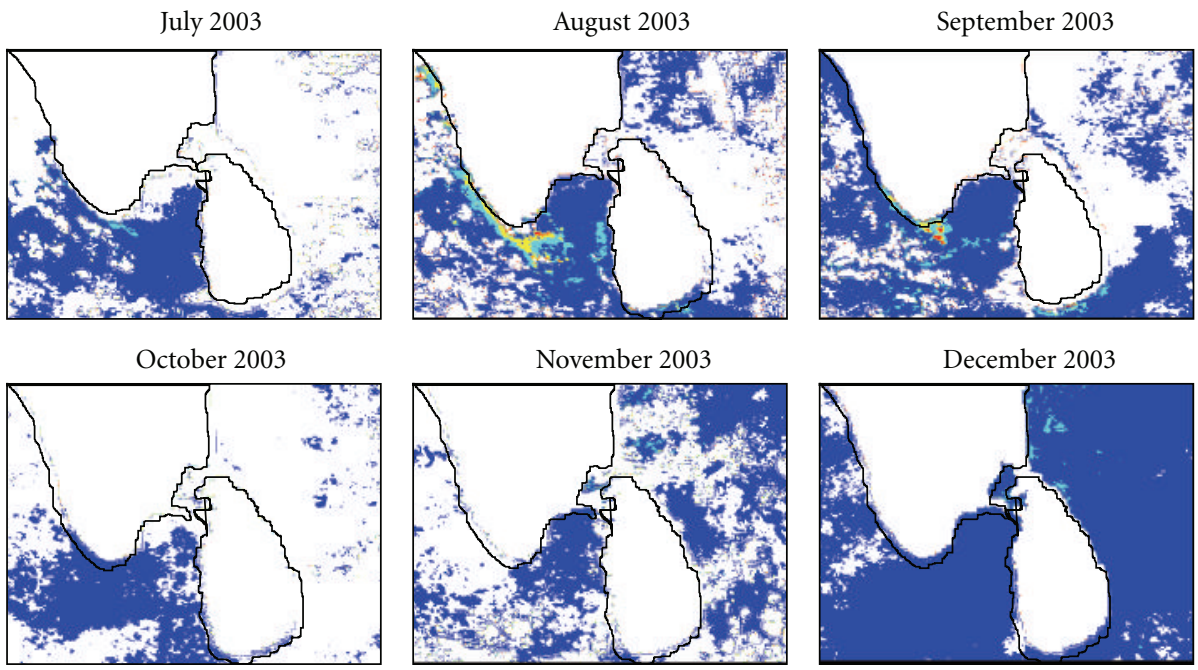

January 2004

February 2004
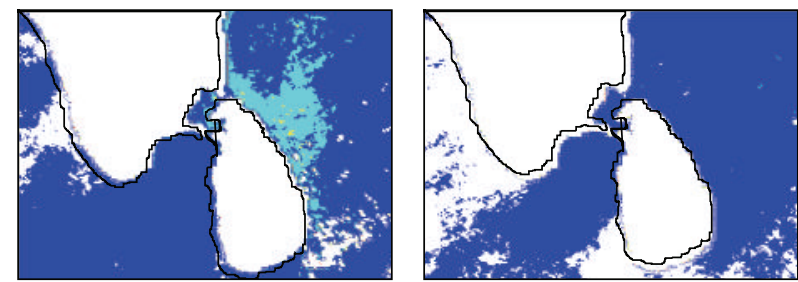

March 2004

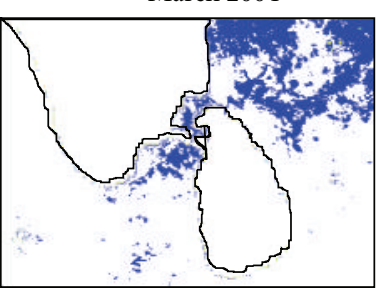

April 2004
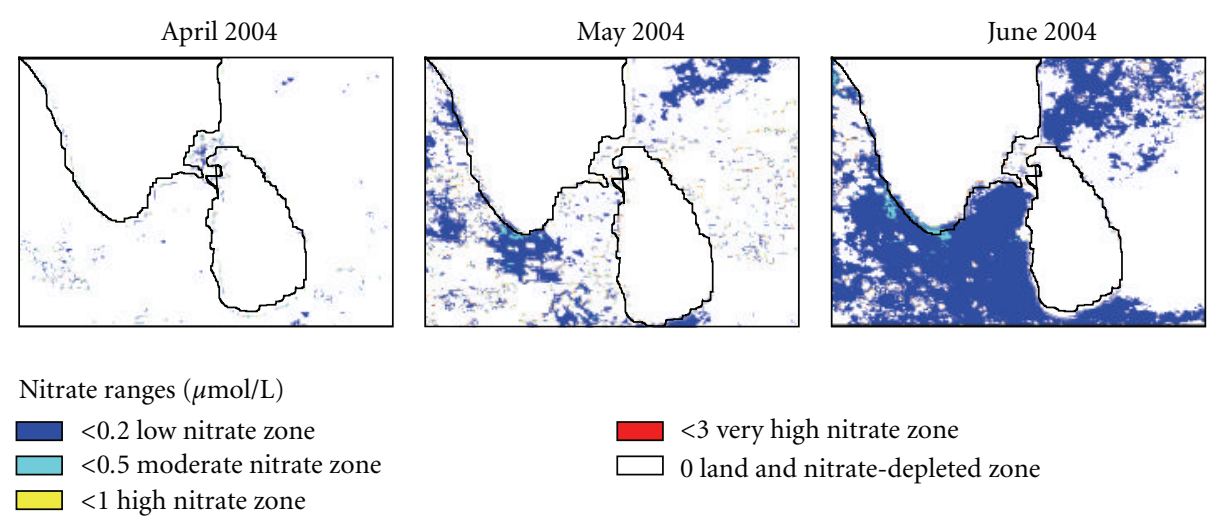

FIGURE 9: In situ nitrate- and temperature-based modelled monthly composite nitrate images during July 2003-June 2004 retrieved from NOAA-AVHRR pathfinder data.

The nitrate mean range is lowest during SIM (0.005$0.02 \mathrm{uM}$ ) (Figure 13). The seasonal trend is as follows: SWM $>$ FIM $>$ NEM $>$ SIM.

4.6.4. Subset 3 (Bay of Bengal). The seasonal mean $\mathrm{NO}_{3}$ range has been highest during the NEM (0.058-0.122 uM) with the year-wise trend $2002>2000>2001>2003>$ 2004. The seasonal nitrate mean range is lowest during SIM (0.001-0.004 uM) (Figure 13). The seasonal trend is as follows: NEM > FIM > SWM > SIM.

\subsection{Standard Deviation (SD) of Nitrate}

4.7.1. Full Image. This indicated the higher variability in the season FIM (Oct.-Nov.) and highest during the year 2000, and variability was lowest during the season SIM (AprilMay) during the year 2003 (Figure 13). The SD trend of the seasonal nitrate is as follows: FIM $>$ SWM $>$ NEM $>$ SIM.

4.7.2. Subset 1. This indicated the higher variability of nitrate in the season FIM (Oct.-Nov.) and highest during the year 2002, and variability was lowest during the season SIM (April-May) during the year 2002 (Figure 13). The SD trend of the seasonal nitrate is as follows: SWM > FIM > SIM > NEM.

4.7.3. Subset 2. This indicated the higher variability of nitrate in the season SWM (Oct.-Nov.) and highest during the year 1999, and variability was lowest during the season SIM (April-May) during the year 2000 (Figure 13). The SD trend of the seasonal nitrate is as follows: SWM > FIM > SIM > NEM. 

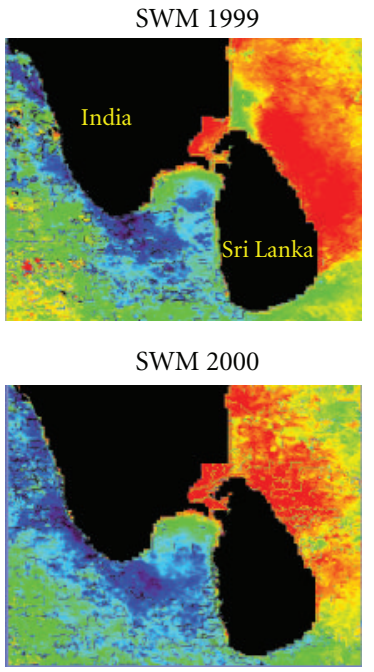

SWM 2001

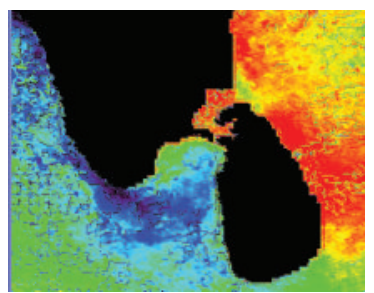

SWM 2002

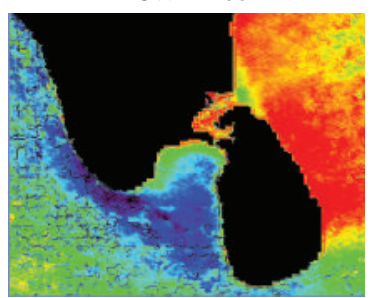

SWM 2003

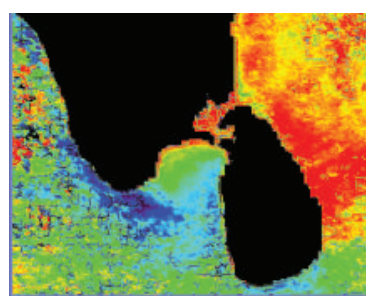

FIM 1999

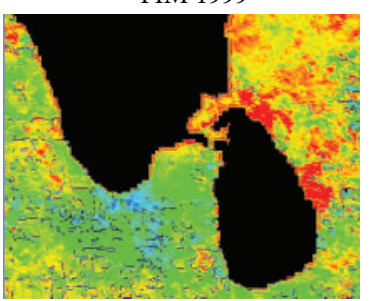

FIM 2000

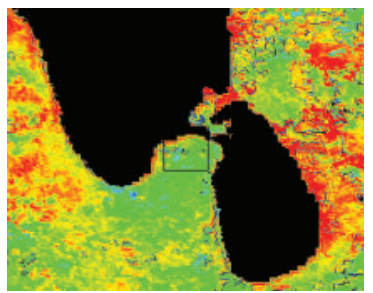

FIM 2001

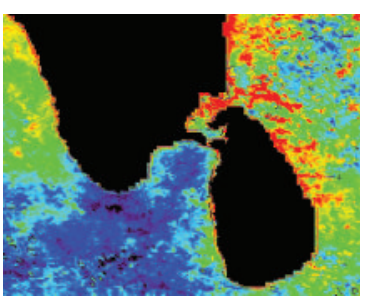

FIM 2002

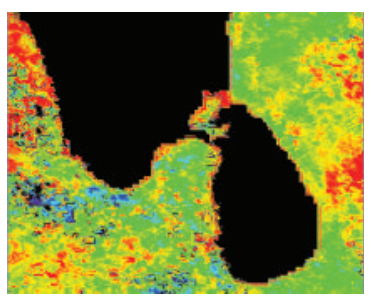

FIM 2003

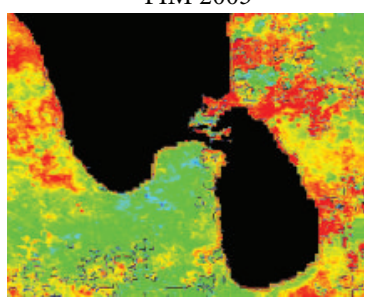

NEM 2000

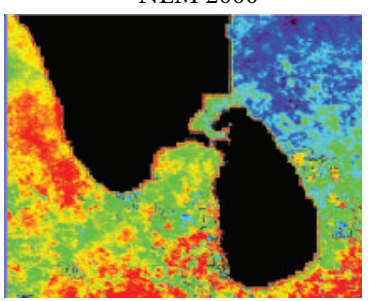

NEM 2001

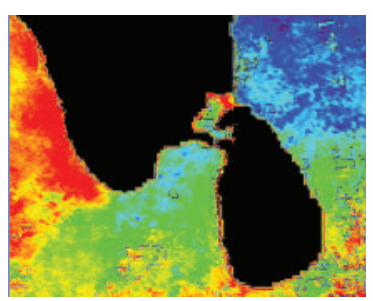

NEM 2002

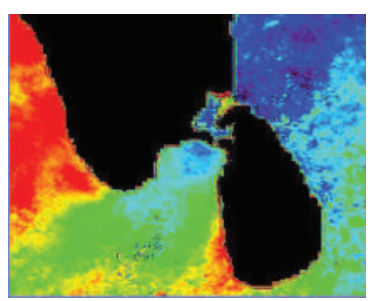

NEM 2003

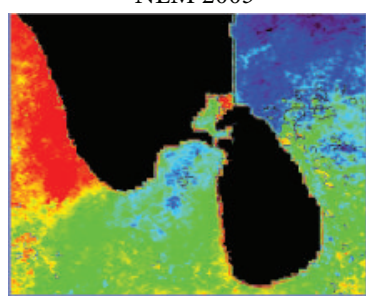

NEM 2004

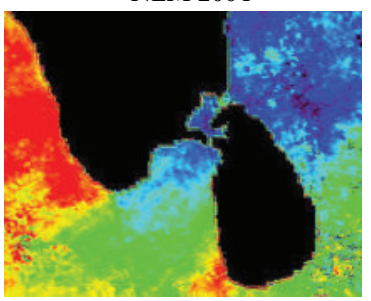

SIM 2000

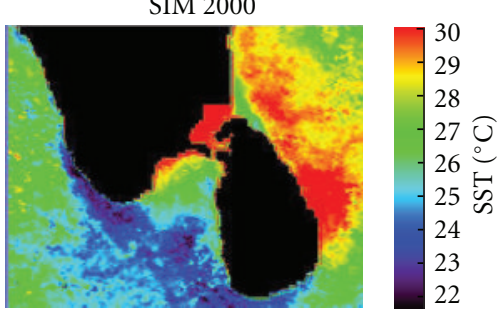

SIM 2001

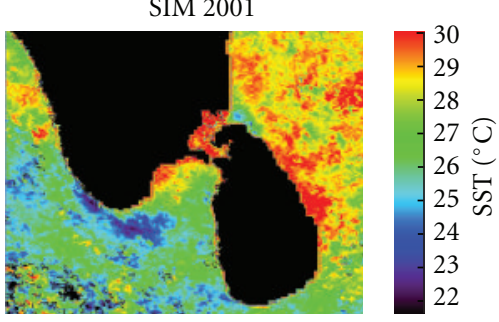

SIM 2002

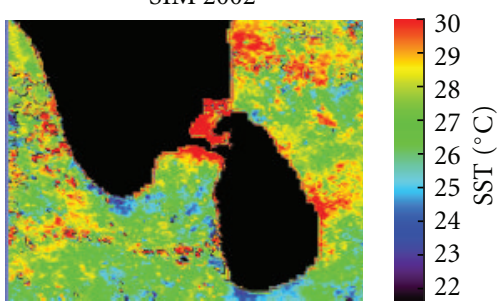

SIM 2003

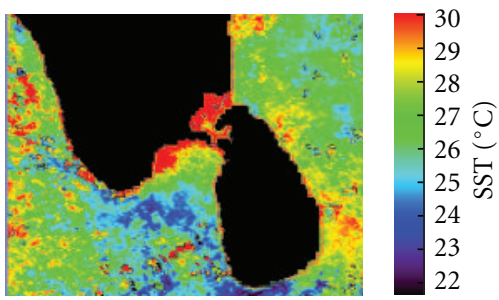

SIM 2004

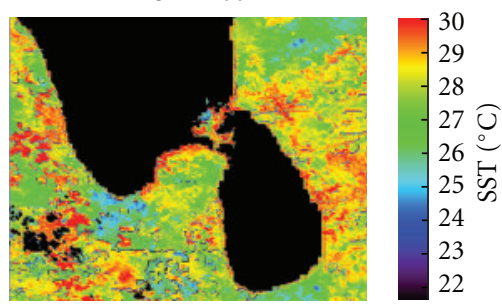

SWM: southwest monsoon (June-September) NEM: northeast monsoon (December-March)
FIM: fall intermonsoon (October-November) SIM: spring intermonsoon (April-May)

FIGURE 10: NOAA-AVHRR derived seasonally averaged SST images during 1999-2004 in the southern peninsular Indian water.

4.7.4. Subset 3. This indicated the higher variability of nitrate in the season FIM (Oct.-Nov.) and highest during the year 1999, and variability was lowest during the season SIM (April-May) during the year 1999 (Figure 13). The SD trend of the seasonal nitrate is as follows: FIM $>$ SWM $>$ NEM > SIM.

The chlorophyll in the Indian Ocean is observed to be primarily dependent on nitrate with some influences of SST and wind speed. But the Arabian Sea and Bay of Bengal chlorophyll is observed to be more dependent on
SST followed by nitrate and then wind speed, obtained from regression analysis of five-year data sets [43]. So the nitrate has been a limiting factor in the ocean productivity around southern peninsular Indian water.

4.8. Annual Variability of Nitrates. The nitrate range has been observed between 0.01 and $0.31 \mu \mathrm{M}$ in the study area. Moderate range $>2.0 \mu \mathrm{M}$ has been observed around the southern and southwest tip of Indian peninsula, off Kerala 


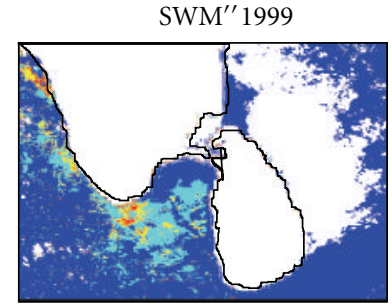

$\mathrm{SWM}^{\prime \prime} 2000$

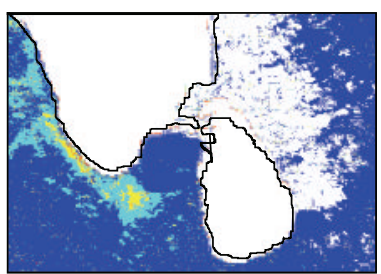

$\mathrm{SWM}^{\prime \prime} 2001$

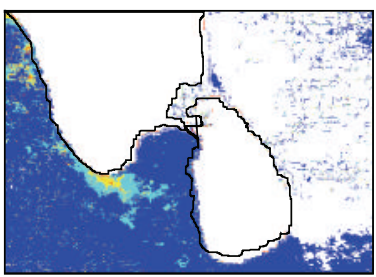

SWM" $^{\prime \prime} 2002$

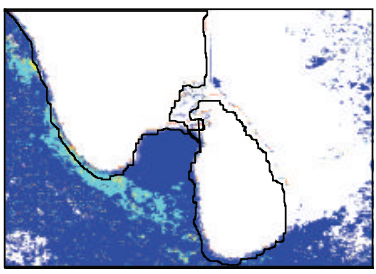

SWM" $^{\prime \prime} 2003$

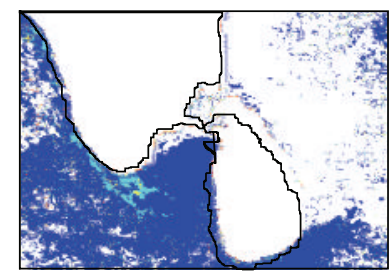

Nitrate ranges $(\mu \mathrm{mol} / \mathrm{L})$

$\square<0.2$ low nitrate zone

$\square<0.5$ moderate nitrate zone

$\square<1$ high nitrate zone

$\square<3$ very high nitrate zone

$\square 0$ land and nitrate-depleted zone

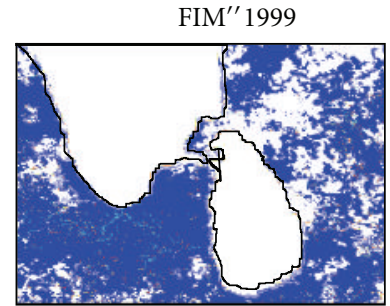

FIM $^{\prime \prime} 2000$

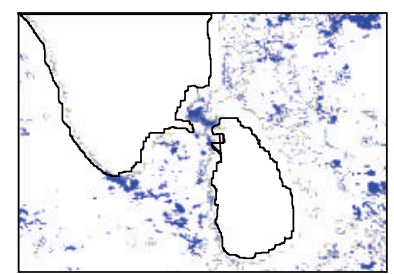

$\mathrm{FIM}^{\prime \prime 2} 2001$

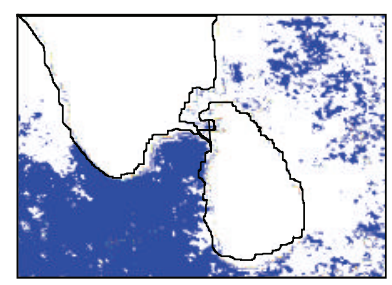

FIM" $^{\prime \prime} 2002$

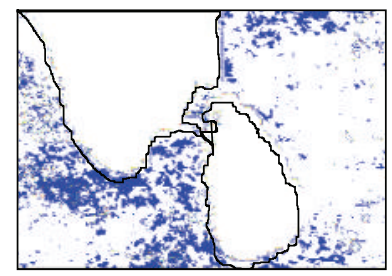

FIM" $^{\prime \prime} 2003$

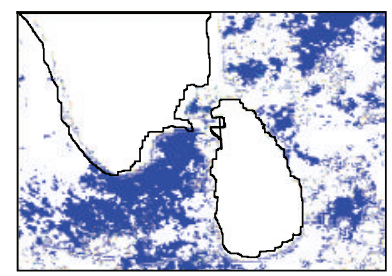

SWM: southwest monsoon

FIM: fall intermonsoon

NEM: northeast monsoon

SIM: spring intermonsoon

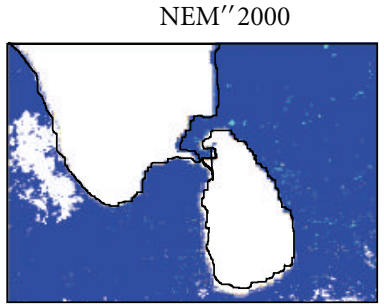

$\mathrm{NEM}^{\prime \prime} 2001$

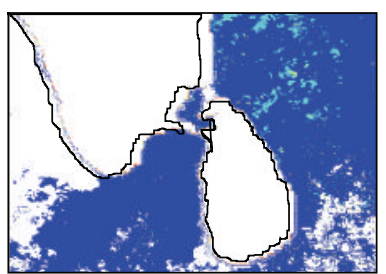

$\mathrm{NEM}^{\prime \prime} 2002$

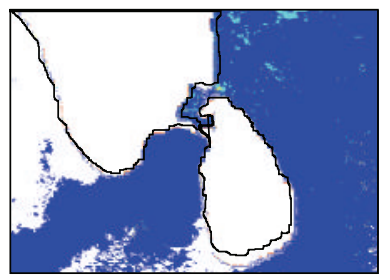

NEM" $^{\prime 2} 2003$

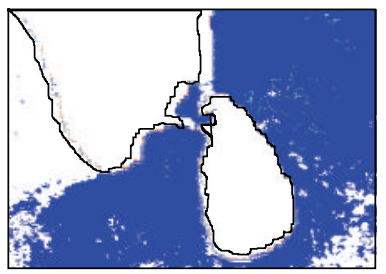

$\mathrm{NEM}^{\prime \prime} 2004$

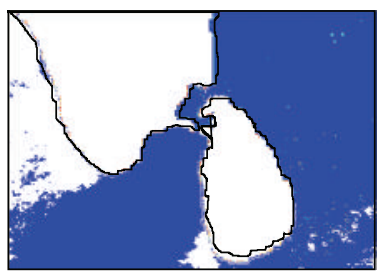

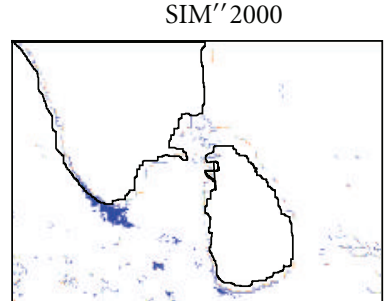

SIM" $^{\prime \prime} 2001$

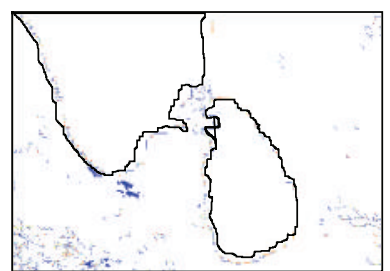

SIM $^{\prime \prime} 2002$

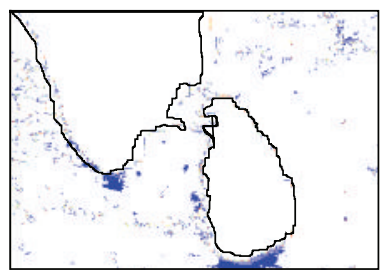

$\mathrm{SIM}^{\prime \prime} 2003$

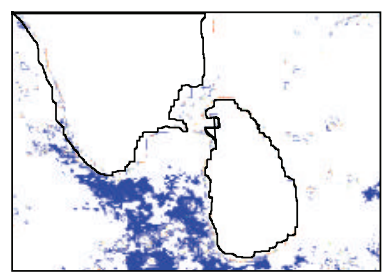

SIM" $^{\prime \prime} 2004$

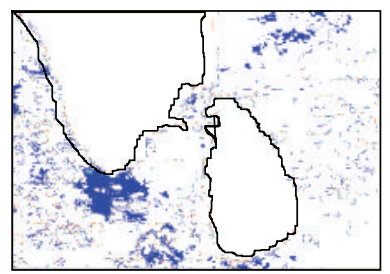

FIGURE 11: In situ nitrate- and temperature-based five years seasonal composite modelled nitrate images during July 1999-June 2004 retrieved from NOAA-AVHRR pathfinder data.

coast, and in the southern Tamilnadu coast in the annual averaged nitrate plot (Figure 13). The peculiar feature has been observed off the southwest coast of India in the Arabian Sea. The high nitrate distribution pattern has been observed, which spreads and moves up to the Sri Lankan coast. This is most probably with the impact of seasonal upwelling off Kerala coast. The coastal water around Kerala is known to be the region of upwelling resulting in a cyclic injection of nutrients into the euphotic zone and pulses of phytoplankton development [14].

During the southwest monsoon, in the Bay of Bengal very few high nitrate concentration patches (around $0.05 \mu \mathrm{M}$ ) are seen to be spread and the rest of the region in the study area indicates low and very low concentration of nitrate 


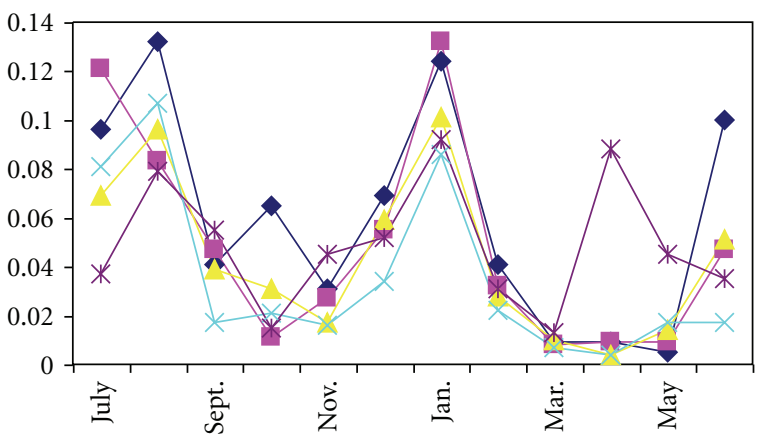

(a)

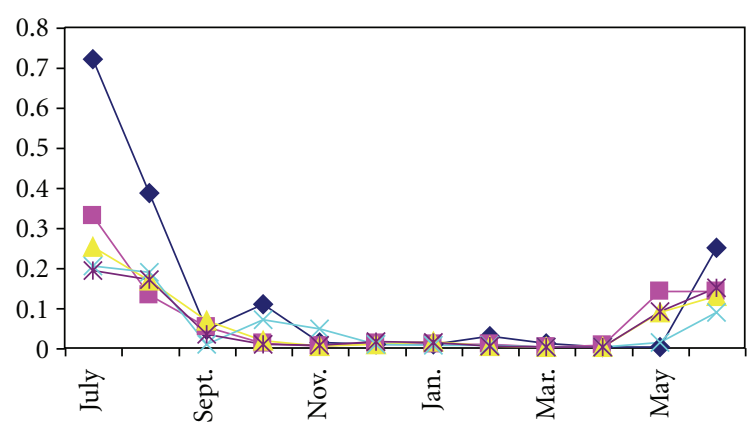

(b)

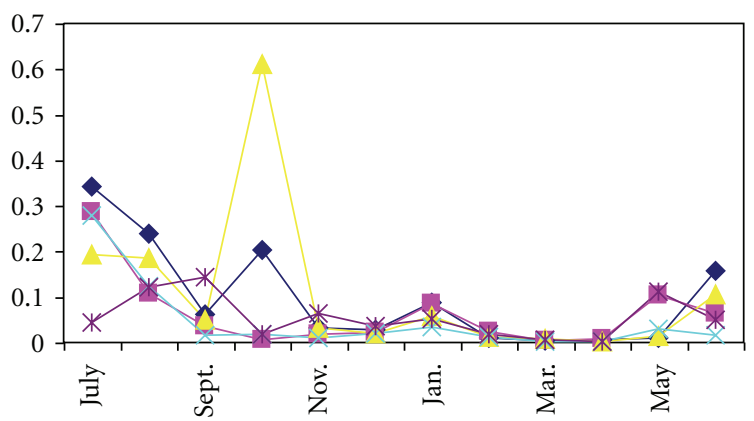

(c)

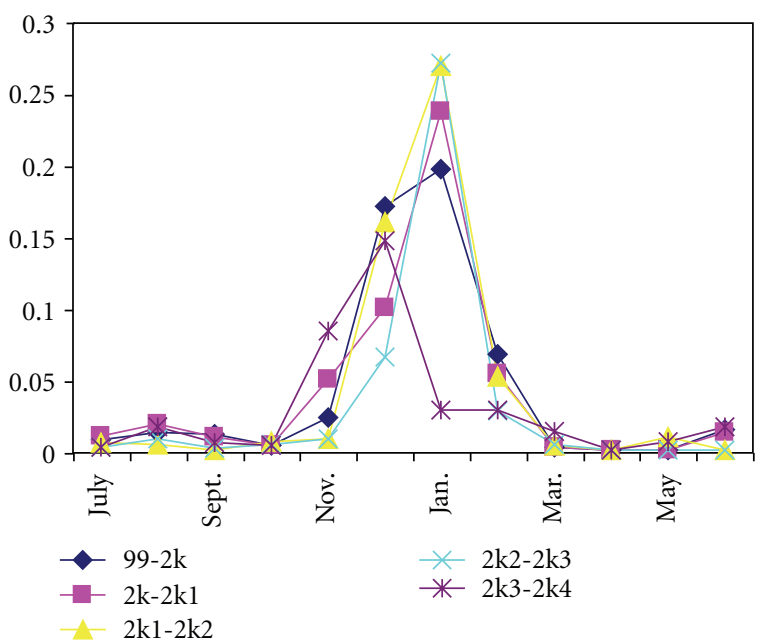

(d)

Figure 12: (a) Full image, (b) subset 1 (Arabian Sea), (c) subset 2 (Indian Ocean), and (d) subset 3 (Bay of Bengal) indicating surface nitrate mean $(\mu \mathrm{M})$ in monthly scale retrieved from temperaturebased in situ modeled data (the annotations on figures $2 \mathrm{k}-2 \mathrm{k} 4$ are mentioned addressing years spanning 2000-2004, resp.).
(0.01-0.2 $\mu \mathrm{M})$. Even in the monthly maps nitrate depletion has been observed significantly, which has been recorded during several cruises in the Bay of Bengal. At present models and algorithms have been developed and applied to know the nitrate depletion temperature (NDT) in the global oceans [44].

The relationship between temperature and nitrate $\left(\mathrm{NO}_{3}\right)$ has been established with significant correlation $\left(R^{2}=0.912\right)$ with the in situ data from U.S. JGOFS and Indian cruises in the Arabian Sea and Bay of Bengal water. The surface nitrate concentration was highest in the Arabian Sea during JuneSeptember (SWM) period, in the Bay of Bengal the nitrate was highest during December-February (NEM), and the Indian Ocean exhibited high nitrate during both the seasons SWM and NEM. The nitrate-depleted zones were seen during April-May period. Upwelling during the SWM has the good link to the high nitrate concentration, enhancing the chlorophyll concentration in the Arabian Sea and around southern tip of India (Indian Ocean).

4.9. Sources of Nitrate and Nitrogen Fixation in Indian Water. The nutrients distribution in the Bay of Bengal is hence influenced by the external inputs which makes the waters of the upper layer less saline and highly stratified $[45,46]$, while the nutrient supply in the Arabian sea is largely due to the seasonal upwelling processes. Additionally the semiannual reversal of the upper-layer circulation also plays a role in transporting the sediments and nutrients through long shore currents in the Bay of Bengal [47-49].

In the northern Indian Ocean, cyanobacteria play a major role in the pelagic food web especially when the upper euphotic zone is stratified and provided with very low concentrations of nitrate $(<0.01 \mu \mathrm{M},[50])$. The Bay of Bengal, in the north eastern region of the Indian Ocean, is known for nitrogen limitation in the surface layers due to strong thermohaline stratification. Stratification prevents the advection of nitrate from the subsurface layer resulting in low biological production in the surface waters $[32,51]$. Although upwelling and subsurface eddies were reported in some regions of the BoB during some seasons, its manifestations on primary production is much less compared to the Arabian Sea [32, 52]. Even during the summer monsoon period, except along the very coastal and upwelling regions of the Bay of Bengal, nitrate remains depleted in the surface layers. Nitrate input from the rivers is restricted to the coastal regions of the Bay of Bengal, and most of the shelf and offshore regions are devoid of any riverine nitrate in the surface layers [32]. The current study depicts high nitrate concentration $(\sim 3.0 \mu \mathrm{M})$ during the southwest monsoon upwelling period during August-September. In the summer time in April-May, there is observation of nitrate-depleted zones in the BoB; this is similar to the analysis in $[32,52]$.

Analyses of seawater collected during two cruises in coastal waters at $18-22^{\circ} \mathrm{N}$ latitude revealed that nitrogen was low in comparison with phosphorus and could be limiting primary production in the surface waters of the Bay [53]. $\mathrm{N}_{2}$-fixation has been observed in all ocean basins, with maximum rates in the Indian Ocean, intermediate rates in 


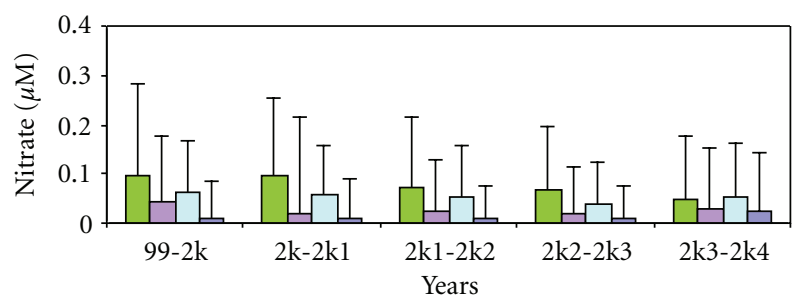

(a)

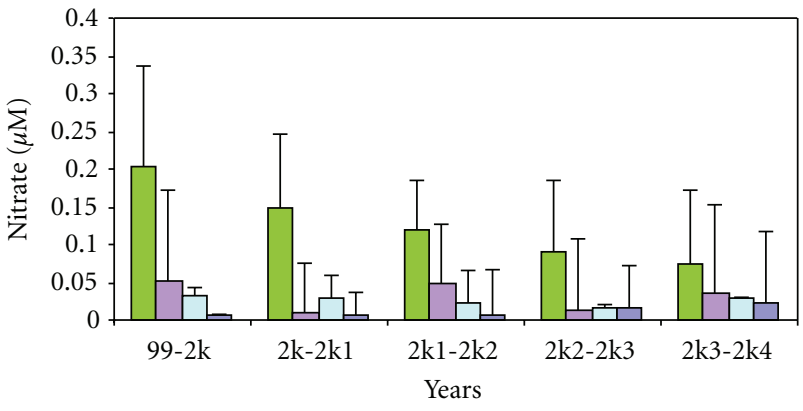

(c)

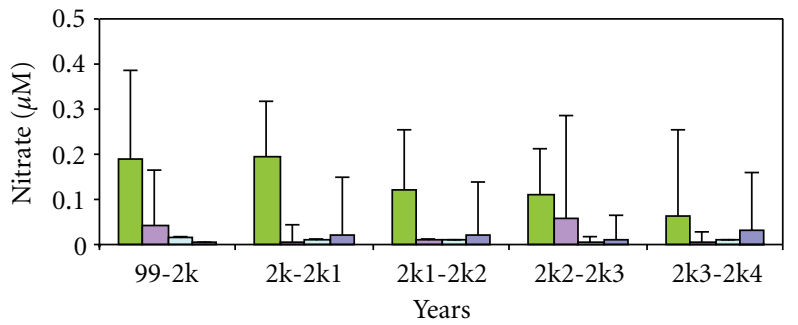

(b)

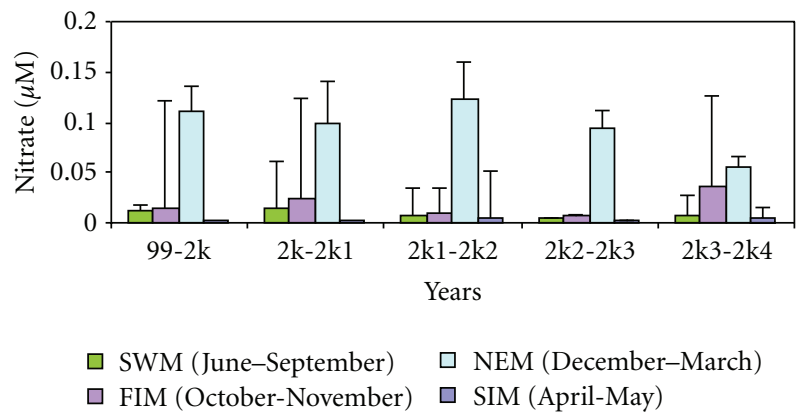

(d)

Figure 13: (a) Full image, (b) subset 1 (Arabian Sea), (c) subset 2 (Indian Ocean), and (d) subset 3 (Bay of Bengal), indicating surface nitrate mean $(\mu \mathrm{M})$ with standar d deviation on seasonal scale retrieved from temperature-based in situ modeled data (SWM: southwest monsoon (June-September), FIM: fall intermonsoon (October-November), NEM: northeast monsoon (December-March), and SIM: summer intermonsoon (April-May)). The annotations on figures $2 \mathrm{k}-2 \mathrm{k} 4$ are mentioned addressing years spanning 2000-2004.

the Atlantic, and minor rates in the Pacific [54]. Nitrogen nutrients are considered to be the major limiting factor of oceanic primary production in many regions [55]. Primary production is partitioned on the basis of nitrogen source: "new" production supported by $\mathrm{N}$-sources, principally nitrate brought into the euphotic zone from the deep and secondarily, $\mathrm{N}_{2}$-fixation, riverine, and atmospheric inputs; "regenerated" production [10] supported by ammonium and urea, derived from biological processes occurring within the euphotic zone [56]. So, the role of nitrate and its uptake in the marine carbon cycle is vital from the point of ocean biogeochemistry in local, regional, and global scales. Detailed analysis on the nitrate sources from upwelling, convective processes, terrestrial fluxes, atmospheric sources, and its characterization would help to understand the nitrogen cycle along with carbon cycle and ocean productivity in Indian water.

\section{Conclusion}

Algorithm for generating surface nitrate concentration in the Indian water covering the Arabian Sea, Bay of Bengal, and adjacent north Indian Ocean has been developed and implemented. The nitrate algorithm which models the satellitederived SST with sigmoid curve has been successfully applied over the Indian water, and the nitrate concentration during the upwelling, southwest, and northeast monsoons has been observed high $(0.50-1.00 \mu \mathrm{M})$. Low-concentration nitrate $(\sim 0.05)$ and nitrate depleting zones have been observed during the summer (March-May) in the Indian water. The nitrate-algorithm-derived surface nitrate maps can be useful for productivity assessment, algal bloom study, and even in the fishery forecasting approaches. The important role of the nitrate maps will be useful in studying nitrate uptake rates by the phytoplankton and the new production zones identification in different water types throughout the year, induced by the physical and biological processes.

\section{Acknowledgments}

The author is thankful to Dr. R. M. Dwivedi, Head, MBD, Dr. Ajai, Group Director, MPSG, Dr. J. S. Parihar, Deputy Director, EPSA, and Dr. R. R. Navalgund, Director, SAC for providing necessary guidance and facilities for carrying out the work. Data archived from U.S. JGOFS archive, NODC/NIO, and Indian cruises have been acknowledged. The author mentions thanks to two anonymous reviewers for their critical overview and suggestions to improve the paper and to make the study more relevant to the regional and global context.

\section{References}

[1] D. Kamykowski, "A preliminary biophysical model of the relationship between temperature and plant nutrients in the upper ocean," Deep Sea Research A, vol. 34, no. 7, pp. 10671079, 1987.

[2] J. D. H. Strickland and T. R. Parsons, "Inorganic carbon assimilation by marine biota," Bulletin/Fisheries Research Board of Canada, vol. 167, article 311, 1968.

[3] H. U. Sverdrup, M. W. Johnson, and R. H. Fleming, The Oceans, Prentice Hall, Englewood Cliffs, NJ, USA, 1942. 
[4] W. S Broecker and T.-H. Peng, Tracers in the Sea, LamontDoherty Geological Observatory, Palisades, NY, USA, 1982.

[5] J. D. H. Strickland, "Research on the marine planktonic food web at the institute of marine resources: a review of the past seven years of work," Oceanography and Marine Biology. An Annual Review, vol. 10, pp. 349-414, 1972.

[6] J. T. O. Kirk, Light and Photosynthesis in Aquatic Ecosystems, Cambridge University Press, Cambridge, UK, 1983.

[7] J. A. Raven, Energetics and Transport in Aquatic Plants, AR Liss, New York, NY, USA, 1984.

[8] S. J. Zentara and D. Kamykowski, "Latitudinal relationships among temperature and selected plant nutrients along the west coast of North and South America," Journal of Marine Research, vol. 35, pp. 321-336, 1977.

[9] H. J. Minas and M. Minas, "Net community production in "high nutrient-low chlorophyll" waters of the tropical and Antarctic oceans: Grazing vs iron hypothesis," Oceanologica Acta, vol. 15, no. 2, pp. 145-162, 1992.

[10] R. C. Dugdale and J. J. Goering, "Uptake of new and regenerated forms of nitrogen in primary productivity," Limnology \& Oceanography, vol. 12, pp. 196-206, 1967.

[11] P. Klein and B. Coste, "Effects of wind-stress variability on nutrient transport into the mixed layer," Deep Sea Research A, vol. 31, no. 1, pp. 21-37, 1984.

[12] E. D. Traganza, V. M. Silva, D. M. Austin, W. L. Hanson, and S. H. Bonsink, "Nutrient mapping and recurrence of coastal upwelling centers by satellite remote sensing: it's implication to primary production and the sediment record," in Coastal Upwelling, Part A, E. Suess and J. Thiede, Eds., pp. 61-83, Plenum, New York, NY, USA, 1983.

[13] R. C. Dugdale, A. Morel, A. Bricaud, and F. P. Wilkerson, "Modeling new production in upwelling centers: a case study of modeling new production from remotely sensed temperature and color," Journal of Geophysical Research, vol. 94, pp. 18119-18132, 1989.

[14] P. Morin, M. V. M. Wafar, and P. Le Corre, "Estimation of nitrate flux in a tidal front from satellite-derived temperature data," Journal of Geophysical Research, vol. 98, no. 3, pp. 46894695, 1993.

[15] R. W. Eppley and B. J. Peterson, "Particulate organic matter flux and planktonic new production in the deep ocean," Nature, vol. 282, no. 5740, pp. 677-680, 1979.

[16] T. Platt, W. G. Harrison, M. R. Lewis et al., "Estimating new production in the sea- a case for a consensus," Marine Ecology Progress Series, vol. 52, pp. 77-88, 1989.

[17] C. Garside and J. C. Garside, "Euphotic-zone nutrient algorithms for the NABE and EqPac study sites," Deep-Sea Research II, vol. 42, pp. 335-342, 1995.

[18] D. Kamykowski and S. J. Zentara, "Predicting plant nutrient concentrations from temperature and sigma-t in the upper kilometer of the world ocean," Deep Sea Research A, vol. 33, no. 1, pp. 89-105, 1986.

[19] S. Sathyendranath, T. Platt, E. P. W. Horne et al., "Estimation of new production in the ocean by compound remote sensing," Nature, vol. 353, no. 6340, pp. 129-133, 1991.

[20] F. P. Chavez and S. K. Service, "Temperature-nitrate relationships in the central and eastern tropical Pacific," Journal of Geophysical Research, vol. 101, no. 9, pp. 20553-20563, 1996.

[21] J. I. Goes, T. Saino, H. Oaku, and D. L. Jiang, "Method for estimating sea surface nitrate concentrations from remotely sensed SST and chlorophyll a-a case study for the north Pacific Ocean using OCTS/ADEOS data," IEEE Transactions on Geoscience and Remote Sensing, vol. 37, no. 3, pp. 1633-1644, 1999.
[22] W. Koeve, "Wintertime nutrients in the north atlantic-new approaches and implications for new production estimates," Marine Chemistry, vol. 74, no. 4, pp. 245-260, 2001.

[23] D. Kamykowski, S. J. Zentara, J. M. Morrison, and A. C. Switzer, "Dynamic global patterns of nitrate, phosphate, silicate, and iron availability and phytoplankton community composition from remote sensing data," Global Biogeochemical Cycles, vol. 16, Article ID 1077, p. 29, 2002.

[24] A. C. Switzer, D. Kamykowski, and S. J. Zentara, "Mapping nitrate in the global ocean using remotely sensed sea surface temperature," Journal of Geophysical Research C, vol. 108, no. 8, Article ID 3280, 12 pages, 2003.

[25] J. I. Goes, H. D. R. Gomes, T. Saino, C. S. Wong, and C. W. Mordy, "Exploiting MODIS data for estimating sea surface nitrate from space," EOS, Transactions, vol. 85, no. 44, pp. 449454, 2004.

[26] S. A. Henson, R. Sanders, C. Holeton, and J. T. Allen, "Timing of nutrient depletion, diatom dominance and a lower-boundary estimate of export production for Irminger Basin, North Atlantic," Marine Ecology Progress Series, vol. 313, pp. 73-84, 2006.

[27] A. Silió-Calzada, A. Bricaud, and B. Gentili, "Estimates of sea surface nitrate concentrations from sea surface temperature and chlorophyll concentration in upwelling areas: a case study for the Benguela system," Remote Sensing of Environment, vol. 112, no. 6, pp. 3173-3180, 2008.

[28] T. Steinhoff, T. Friedrich, S. E. Hartman, A. Oschlies, D. W. R. Wallace, and A. Körtzinger, "Estimating mixed layer nitrate in the North Atlantic Ocean," Biogeosciences, vol. 7, no. 3, pp. 795-807, 2010.

[29] J. I. Goes, H. D. R. Gomes, A. Limsakul, and T. Saino, “The influence of large-scale environmental changes on carbon export in the North Pacific Ocean using satellite and shipboard data," Deep Sea Research II, vol. 51, no. 1-3, pp. 247-279, 2004.

[30] D. M. Bartolacci and M. E. Luther, "Patterns of co-variability between physical and biological parameters in the Arabian Sea," Deep-Sea Research II, vol. 46, no. 8-9, pp. 1933-1964, 1999.

[31] J. S. Sarupria and R. M. S. Bhargava, "Seasonal distribution of chlorophyll-a in the exclusive economic zone (EEZ) of India," Indian Journal of Marine Sciences, vol. 27, pp. 292-297, 1998.

[32] S. Prasanna Kumar, P. M. Muraleedharan, T. G. Prasad et al., "Why is the Bay of Bengal less productive during summer monsoon compared to the Arabian Sea?" Geophysical Research Letters, vol. 29, Article ID 2235, 4 pages, 2002.

[33] P. H. Burkill, R. F. C. Mantoura, and N. J. P. Owens, "Biogeochemical cycling in the northwestern Indian Ocean: a brief overview," Deep-Sea Research II, vol. 40, no. 3, pp. 643649, 1993.

[34] S. R. Shetye, A. D. Gouveia, and S. S. C. Shenoi, "Circulation and water masses of the Arabian Sea," Proceedings of the Indian Academy of Sciences: Earth and Planetary Sciences, vol. 103, no. 2, pp. 107-123, 1994.

[35] M. Madhupratap, T. C. Gopalakrishnan, P. Haridas et al., "Lack of seasonal and geographic variation in mesozooplankton biomass in the Arabian Sea and its structure in the mixed layer," Current Science, vol. 71, no. 11, pp. 863-868, 1996.

[36] M. Madhupratap, S. P. Kumar, P. M. A. Bhattathiri et al., "Mechanism of the biological response to winter cooling in the northeastern Arabian Sea," Nature, vol. 384, no. 6609, pp. 549-552, 1996.

[37] M. Madhupratap, M. Gauns, N. Ramaiah et al., "Biogeochemistry of the Bay of Bengal: physical, chemical and primary productivity characteristics of the central and western Bay of 
Bengal during summer monsoon 2001," Deep Sea Research II, vol. 50, no. 5, pp. 881-896, 2003.

[38] J. M. Morrison, L. A. Codispoti, S. Gaurin, B. Jones, V. Manghnani, and Z. Zheng, "Seasonal variation of hydrographic and nutrient fields during the US JGOFS Arabian Sea Process Study," Deep-Sea Research II, vol. 45, no. 10-11, pp. 2053-2101, 1998.

[39] March 2008, http://www.nodc.noaa.gov/sog/pathfinder4km/ userguide.html.

[40] R. K. Sarangi, S. Nayak, and R. C. Panigraphy, "Monthly variability of chlorophyll and associated physical parameters in the southwest Bay of Bengal water using remote sensing data," Indian Journal of Marine Sciences, vol. 37, no. 3, pp. 256266, 2008.

[41] JGOFS, "Protocols for the Joint Global Ocean Flux Study (JGOFS) core measurements," Tech. Rep. 19, Intergovernmental Oceanographic Commission, Bergen, Norway, 1996.

[42] S. R. Nayak, R. K. Sarangi, and A. S. Rajawat, "Application of IRS-P4 OCM data to study the impact of cyclone on coastal environment of Orissa," Current Science, vol. 80, no. 10, pp. 101-106, 2001.

[43] R. K. Sarangi, Impact of surface feature changes on the phytoplankton variability in Seas off the southern parts of the Indian Peninsula: a remote sensing approach, Ph.D. thesis, Berhampur University, Orissa, India, 2007.

[44] D. Kamykowski and S. J. Zentara, "Can phytoplankton community structure be inferred from satellite-derived sea surface temperature anomalies calculated relative to nitrate depletion temperatures?" Remote Sensing of Environment, vol. 86, no. 4, pp. 444-457, 2003.

[45] V. Subramanian, "Sediment load of Indian rivers," Current Science, vol. 64, pp. 928-930, 1993.

[46] P. N. Vinayachandran and S. Mathew, "Phytoplankton bloom in the Bay of Bengal during the northeast monsoon and its intensification by cyclones," Geophysical Research Letters, vol. 30, Article ID 1572, 4 pages, 2003.

[47] J. P. McCreary, W. Han, D. Shankar, and S. R. Shetye, "Dynamics of the East India coastal current, numerical solutions," Journal of Geophysical Research C, vol. 101, no. 6, pp. 13993-14010, 1996.

[48] P. N. Vinayachandran, S. R. Shetye, D. Sengupta, and S. Gadgil, "Forcing mechanisms of the Bay of Bengal circulation," Current Science, vol. 71, no. 10, pp. 753-763, 1996.

[49] D. Shankar, J. P. McCreary, W. Han, and S. R. Shetye, "Dynamics of the East India Coastal Current 1. Analytic solutions forced by interior Ekman pumping and local alongshore winds," Journal of Geophysical Research C, vol. 101, pp. 1397513991, 1996.

[50] P. H. Burkill, R. J. G. Leaky, N. J. P. Owens, and R. F. C. Mantoura, "Synechococcus and its importance in the microbial food web of the northern Indian Ocean," Deep Sea Research II, vol. 40, pp. 773-782, 1992.

[51] H. R. Gomes, J. I. Goes, and T. Saino, "Influence of physical processes and freshwater discharge on the seasonality of phytoplankton regime in the Bay of Bengal," Continental Shelf Research, vol. 20, no. 3, pp. 313-330, 2000.

[52] S. Prasanna Kumar, M. Nuncio, J. Narvekar et al., "Are eddies nature's trigger to enhance biological productivity in the Bay of Bengal?" Geophysical Research Letters, vol. 31, no. 7, Article ID L07309, 5 pages, 2004.

[53] C. P. Valsaraj and V. N. R. Rao, "Nitrogen limitation in the tropical waters of the Bay of Bengal," Hydrobiologia, vol. 286, no. 3, pp. 139-148, 1994.
[54] D. G. Capone and E. J. Carpenter, "Nitrogen fixation in the marine environment," Science, vol. 217, no. 4565, pp. 1140 1142, 1982.

[55] W. G. Harrison, T. Platt, and M. R. Lewis, " $f$-ratio and its relationship to ambient nitrate concentration in coastal waters," Journal of Plankton Research, vol. 9, no. 1, pp. 235248, 1987.

[56] N. Gandhi, S. Prakash, R. Ramesh, and S. Kumar, "Nitrogen uptake rates and new production in the Northern Indian Ocean," Indian Journal of Marine Sciences, vol. 39, no. 3, pp. 362-368, 2010. 

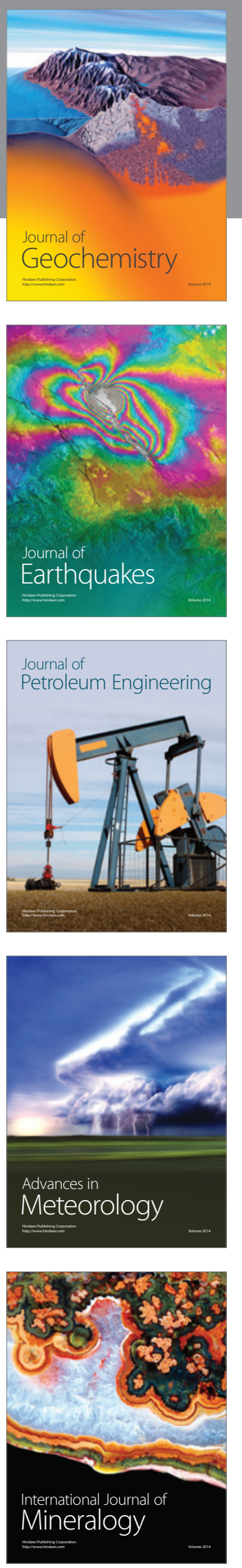
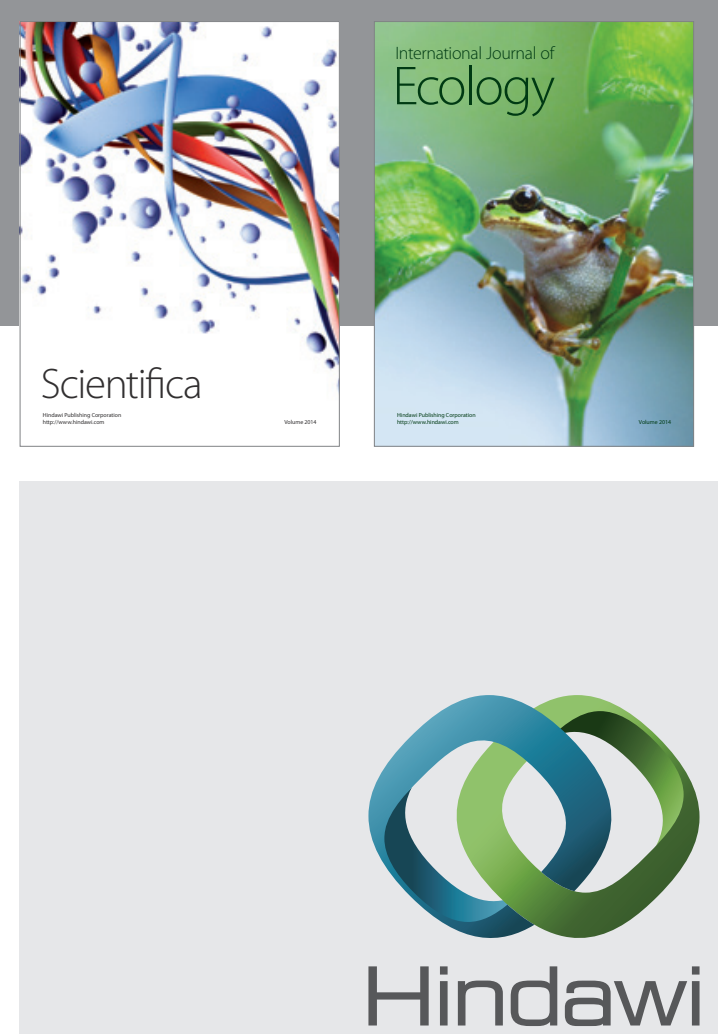

Submit your manuscripts at http://www.hindawi.com
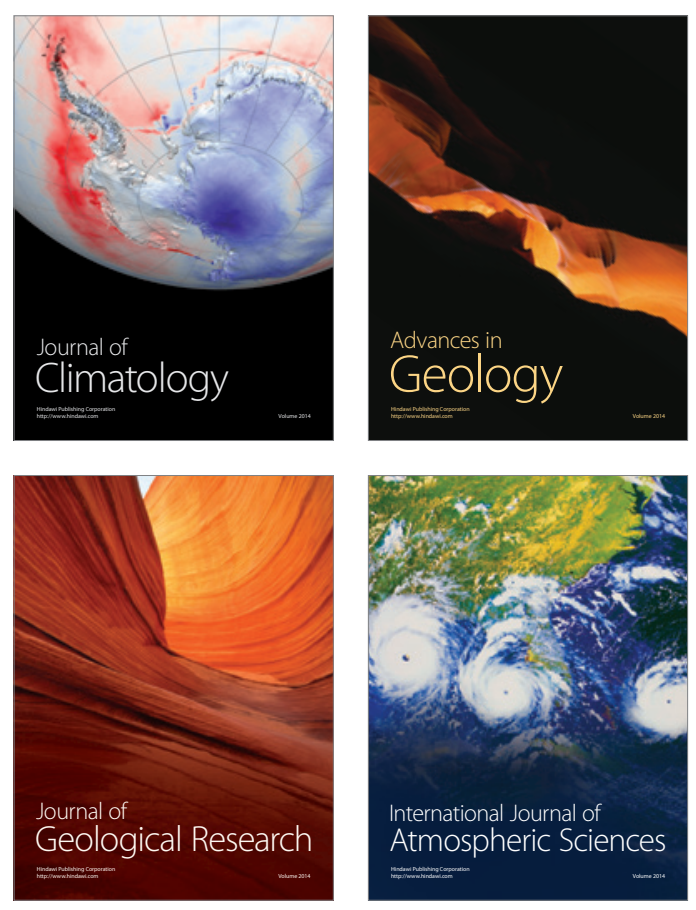
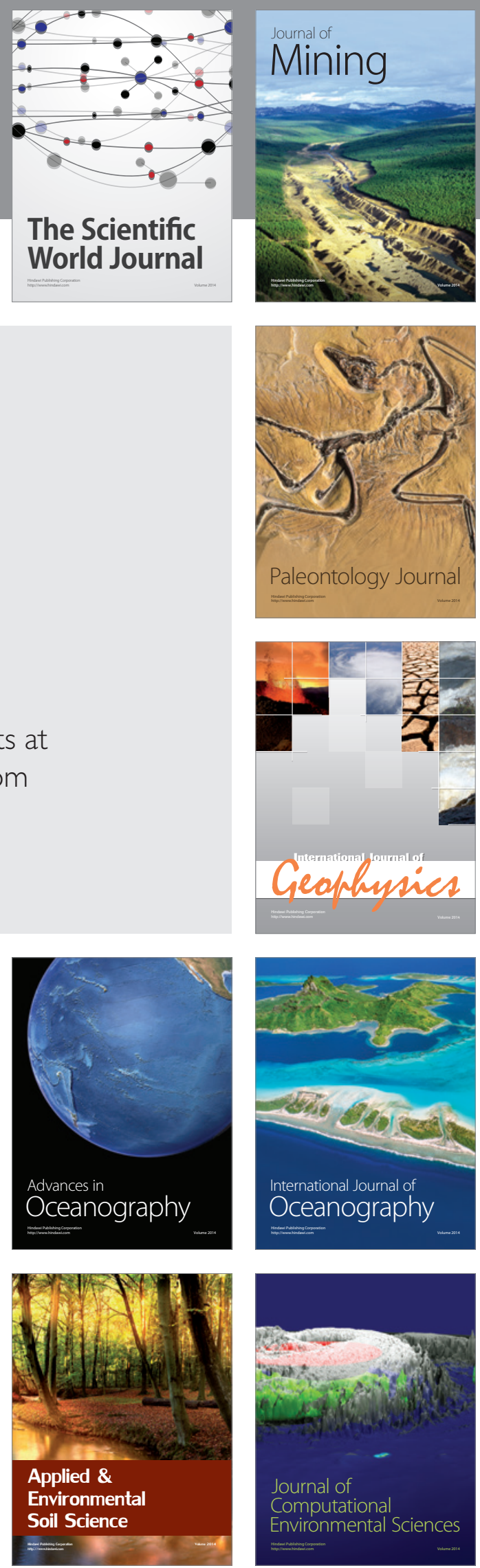